\title{
NOWE DANE NA TEMAT OBRZĄDKU POGRZEBOWEGO KULTURY AMFOR KULISTYCH Z ZACHODNIEJ LUBELSZCZYZNY
}

\author{
NEW DATA ON GLOBULAR AMPHORA CULTURE FUNERAL RITES \\ FROM WESTERN LUBLIN REGION
}

\begin{abstract}
Abstrakt: Pomimo bardzo dobrego stopnia rozpoznania podgrupy nałęczowskiej kultury amfor kulistych, odkrycie grobu typu nałęczowskiego w Końskowoli oraz ponowna interpretacja grobu z Puław-Włostowic rzuciły nowe światło na obrządek pogrzebowy i zasięg oddziaływań społeczności tej kultury w zachodniej części Lubelszczyzny. Oba stanowiska położone są poza zwartą strefą występowania tego typu obiektów i oba znajdują się poza obszarem wysoczyznowym Płaskowyżu Nałęczowskiego. Groby z Puław-Włostowic i Końskowoli pod względem wyposażenia i w przypadku drugiego ze stanowisk także pod względem surowca wykorzystanego do konstrukcji komory grobowej odbiegają nieco od „klasycznych” obiektów typu nałęczowskiego. Najprawdopodobniej reprezentują najmłodszą fazę osadnictwa podgrupy nałęczowskiej kultury amfor kulistych.
\end{abstract}

Słowa kluczowe: kultura amfor kulistych, podgrupa nałęczowska, obrządek pogrzebowy, Końskowola, Puławy-Włostowice, Polska

\begin{abstract}
The discovery of the Nałęczów type grave in Końskowola as well as the reinterpretation of the grave from Puławy-Włostowice has shed new light on the funeral rite and range of influences of the Nałęczów subgroup of the Globular Amphora culture in the western part of the Lublin region. Both sites are located outside the compact zone where features of this site occur and outside the upland area of the Nałęczów Plateau. The graves from Puławy-Włostowice and Końskowola differ slightly from the "classic" features of the Nałęczów type in terms of their burial goods, and in Końskowola, the raw material used for the construction of the burial chamber. They most likely represent the youngest phase of settlement of the Nałęczów subgroup in the Globular Amphorae culture.
\end{abstract}

Keywords: Globular Amphora culture, Nałęczów subgroup, funeral rite, Końskowola, Puławy-Włostowice, Poland

${ }^{a}$ Mgr Tadeusz Wiśniewski, Instytut Archeologii, Uniwersytet Marii Curie-Skłodowskiej, Plac Marii Curie-Skłodowskiej 4, 20-031 Lublin, krzem7@o2.pl, ORCID iD: https://orcid.org/0000-00030107-3220.

${ }^{b}$ Dr Barbara Niezabitowska-Wiśniewska, Instytut Archeologii, Uniwersytet Marii Curie-Skłodowskiej, Plac Marii Curie-Skłodowskiej 4, 20-031 Lublin, barbara.niezabitowska-wisniewska@poczta. umcs.lublin.pl, baica@poczta.onet.pl, ORCID iD: https://orcid.org/0000-0001-7557-4488. 
Obrządek pogrzebowy ludności kultury amfor kulistych na Lubelszczyźnie jest bardzo zróżnicowany. W jej zachodniej części wydzielona została podgrupa nałęczowska, przy czym największe skupisko tworzących ją stanowisk znajduje się na Płaskowyżu Nałęczowskim (Nosek [1950] 1954/1955, s. 124-128; tenże 1967, s. 341, 344-345; Wiślański 1966, s. 88-89; Ścibior 1984; 1985a; 1991). Tym samym $\mathrm{z}$ reguły lokowane są one na obszarach wysoczyznowych, często na kulminacjach wzniesień i przeważnie w niewielkiej odległości od cieków wodnych lub w bezpośredniej ich bliskości (Bronicki 2016, s. 226-227). Cechą charakterystyczną grobów tzw. typu nałęczowskiego jest obecność wykonanych z bloków wapiennych obstaw, pokryw i bruków na dnie. Wszystkie trzy elementy konstrukcyjne występują jednak stosunkowo rzadko, choć obraz ten może być znacznie zniekształcony w wyniku stanu zachowania grobowców. Andrzej Bronicki w obszernym opracowaniu na temat obrządku pogrzebowego społeczności kultury amfor kulistych na Wyżynie Lubelskiej opublikowanym w 2016 r. wydzielił 6 grup konstrukcyjnych grobów typu nałęczowskiego, za kryterium podziału przyjmując współwystępowanie wszystkich lub wybranych elementów konstrukcji (Bronicki 2016, s. 229-232). Znaczny odsetek grobów typu nałęczowskiego zawiera pochówki zbiorowe. Występują również obiekty, w których oprócz szkieletów ludzkich odkryto szczątki zwierzęce, zarówno w postaci pojedynczych kości, jak i całych lub prawie całych zwierząt, głównie krów. Wśród wyposażenia dominują naczynia gliniane, narzędzia krzemienne, w tym głównie siekiery wykonane w zdecydowanej większości z krzemienia pasiastego a także wyroby z bursztynu, kości czy poroża oraz kły dzika lub świni. Za powszechną praktykę ludności kultury amfor kulistych z podgrupy nałęczowskiej przyjęło się także uważać palenie ognia w komorach grobowych (Bronicki 2016, s. 239, 244-251, tabela 12). Według najnowszych zestawień podgrupę nałęczowską tworzą 24 stanowiska grobowe, z czego aż 20 położonych jest na Płaskowyżu Nałęczowskim (Ścibior 1985a; 1991, s. 58-60; Bronicki 2016, s. 225-227).

Od przedstawionego powyżej schematu obrządku pogrzebowego kultury amfor kulistych z zachodniej Lubelszczyzny wydają się w kilku aspektach odbiegać dwa groby odkryte w Puławach-Włostowicach (stan.3) i w Końskowoli (stan. 12), w powiecie puławskim. Choć obiekty te włączyć można do podgrupy nałęczowskiej kultury amfor kulistych, już samo ich położenie zdecydowanie różni się od lokalizacji pozostałych grobów. Obiekt z Puław-Włostowic usytuowany jest na terasie nadzalewowej Wisły, w obrębie Małopolskiego Przełomu Wisły (Reder 2018; Jakubczak 2018) i do niedawna uważany był za jedyny obiekt typu nałęczowskiego na Lubelszczyźnie znajdujący się poza obszarem lessowej wysoczyzny (Matyaszewski, Miliszkiewicz 1978). Natomiast grób z Końskowoli usytuowany jest na krawędzi doliny rzeki Kurówki, na południowo-zachodnim skraju Wysoczyzny Lubartowskiej, stanowiącej część Niziny Południowopodlaskiej (Kondracki 2009, s. 206). Oba stanowiska położone są też w niewielkiej odległości od Płaskowyżu Nałęczowskiego, przy czym grób z Końskowoli znajduje się około 2,8km w linii prostej od północnej krawędzi tego mezoregionu, zaś grób z Puław-Włostowic o niespełna $200 \mathrm{~m}$ od jego krawędzi zachodniej. Oba stanowiska oddalone są od siebie o około 5,5 km w linii prostej (ryc. 1). 
The funeral rite of the population of Globular Amphora culture in the Lublin region is very diverse. In its western part, the Nałęczów subgroup has been separated, with the largest cluster of forming it sites being located on the Nałęczów Plateau (Nosek [1950] 1954/1955, pp. 124-128; idem 1967, pp. 341, 344-345; Wiślański 1966, pp. 88-89; Ścibior 1984; 1985a; 1991). As a rule, they are located in the upland areas, often at the culmination of elevations and usually only a short distance from watercourses or in their immediate vicinity (Bronicki 2016, pp. 226-227). A characteristic trait of the graves of the so-called Nałęczów type is the presence of linings, covers and pavements on the bottom, made of limestone slabs. All three structural components, however, occur relatively rare, although this image can be significantly distorted as a result of the state of preservation of the tombs. Andrzej Bronicki in a comprehensive study on the funeral rite of the Globular Amphora culture community in the Lublin Upland published in 2016, separated 6 structural groups of Nałęczów type graves, for the division criterion assuming the co-occurrence of all or selected structural components (Bronicki 2016, pp. 229-232). A significant percentage of Nałęczów type graves includes multiple burials. There are also features in which, apart from human skeletons, animal remains have been discovered, both in the form of individual bones, as well as whole or almost entire animals, mainly cows. The grave goods are dominated by clay vessels, flint tools, mainly axes made mostly of banded flint as well as products of amber, bones or antlers and boar's or pig's tusks. The practice of lighting a fire in the burial chambers (Bronicki 2016, pp. 239, 244-251, Table 12) was also widely considered to be common practice of the population of the Globular Amphora culture from the Nałęczów subgroup. According to the latest juxtaposing, the subgroup of Nałęczów consists of 24 grave sites, of which 20 are located on the Nałęczów Plateau (Ścibior 1985a; 1991, pp. 58-60; Bronicki 2016, pp. 225-227).

From the above-described funeral rite scheme of the Globular Amphora culture from the western Lublin region seem to diverge in several aspects two graves discovered in Puławy-Włostowice (site 3) and in Końskowola (site 12), in the Puławy district. Although these features can be included in the Nałęczów subgroup of the Globular Amphora culture, just their location is definitely different from the location of the other graves. The feature from Puławy-Włostowice is located on a Vistula meadow terrace, within the Lesser Poland Gorge of the Vistula (Reder 2018; Jakubczak 2018) and until recently was considered the only feature of the Nałęczów type in the Lublin region located outside the loess plateau (Matyaszewski, Miliszkiewicz 1978). The grave from Końskowola, on the other hand, is situated on the edge of the valley of River Kurówka, on the south-western edge of the Lubartów Plateau, which is part of the South Podlasie Lowland (Kondracki 2009, p. 206). Both sites are also located a short distance from the Nałęczów Plateau, wherein the grave from Końskowola is located about $2.8 \mathrm{~km}$ in a straight line from the northern edge of this mesoregion, while the grave from Puławy-Włostowice is situated less than $200 \mathrm{~m}$ from its western edge. Both sites are approximately $5.5 \mathrm{~km}$ apart in a straight line (Fig. 1).

The grave from Puławy-Włostowice, discovered in 1977, was included in the above-mentioned and published less than three years ago work of A. Bronicki 


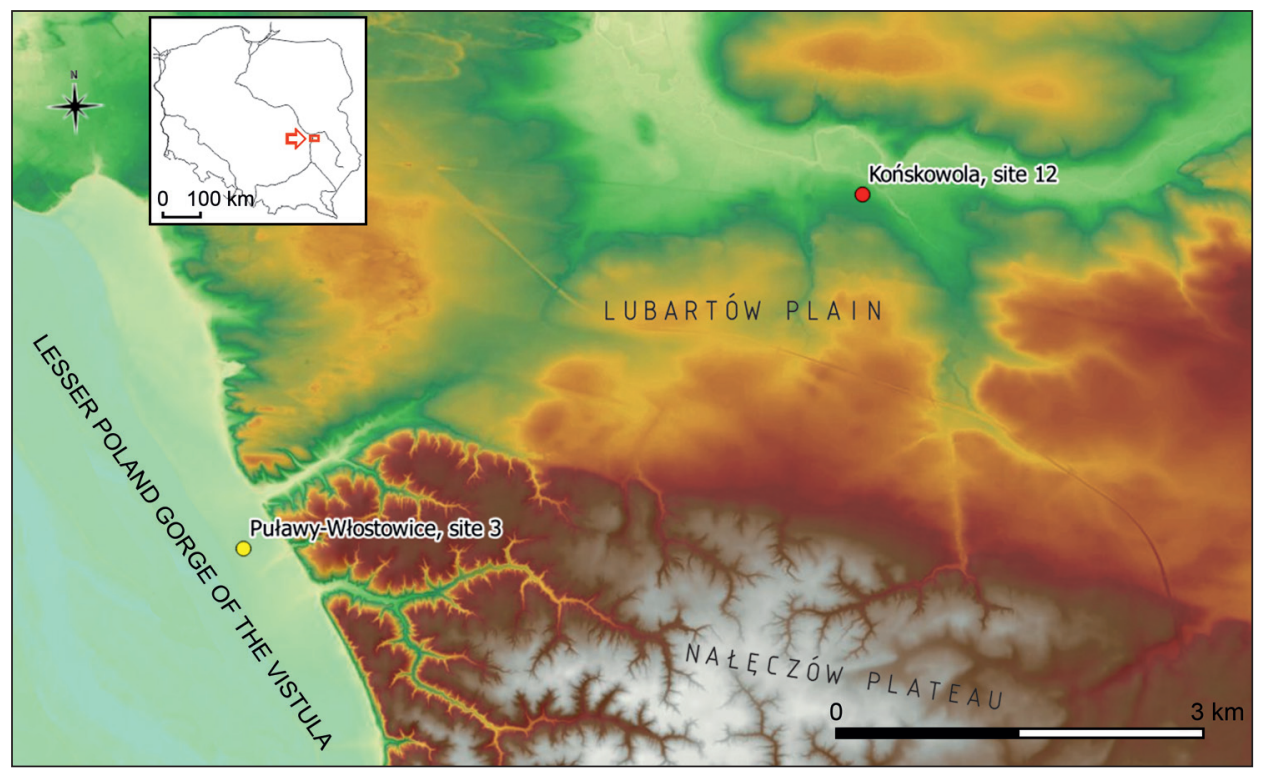

Ryc. 1. Lokalizacja stanowisk kultury amfor kulistych w Końskowoli (stan. 12) i Puławach-Włostowicach (stan. 3).

Wg http://mapy.geoportal.gov.pl/imap/Imgp_2.html?gpmap=gp0

Fig. 1. Location of sites of the Globular Amphora culture in Końskowola (site 12) and Puławy-Włostowice (site 3).

After to http://mapy.geoportal.gov.pl/imap/Imgp_2.html?gpmap=gp0

Grób z Puław-Włostowic, odkryty w 1977 r., uwzględniony został we wspomnianej już i opublikowanej niespełna trzy lata temu pracy A. Bronickiego (2016, s. 217-221), przy czym ze względu na zaginięcie dokumentacji wykopaliskowej jego opis oparty został na pracy magisterskiej Józefa Ścibiora (1984, s. 101-103) i sprawozdaniu z badań (Matyaszewski, Miliszkiewicz 1978). Informacje zawarte w tym opracowaniu ostatnio zostały zweryfikowane i uzupełnione (Niezabitowska-Wiśniewska, Wiśniewski 2018) (ryc. 2e-f; 3h-q; 4). Tym samym, w niniejszym artykule zostały ujęte jedynie w tabeli (tabela 1) i uwzględnione w analizie. Przedstawiony zostanie natomiast opis niepublikowanego dotąd grobu z Końskowoli.

\section{GRÓB KULTURY AMFOR KULISTYCH Z KOŃSKOWOLI}

\section{OKOLICZNOŚCI ODKRYCIA}

Grób odkryty został przypadkowo w 2014 r. w trakcie prac ziemnych związanych z przebudową napowietrznej stacji transformatorowej Końskowola 7 oraz linii elektroenergetycznych przy ulicy Kurowskiej $71 \mathrm{w}$ tej miejscowości, a tym samym został częściowo zniszczony przez koparkę w trakcie kopania wykopu pod kabel. $\mathrm{Na}$ 
(2016, pp. 217-221), however, due to the loss of the excavation documentation its description was based on Master's thesis of Józef Ścibior (1984, pp. 101-103) and on research report (Matyaszewski, Miliszkiewicz 1978). The information contained in this study has recently been verified and supplemented (Niezabitowska-Wiśniewska, Wiśniewski 2018) (Figs 2e-f; 3h-q; 4). Thus, in this article they are included only in the table (Table 1) and taken into account in the analysis. Instead, will be presented a description of the so far unpublished grave from Końskowola.

\section{GRAVE OF GLOBULAR AMPHORA CULTURE FROM KOŃSKOWOLA}

\section{CIRCUMSTANCES OF DISCOVERY}

The grave was discovered accidentally in 2014 during earthworks related to the reconstruction of the overhead transformer substation Końskowola 7 and the power lines at Kurowska 71 street in this town, and thus was partially destroyed by the excavator while digging the cable trench. Numerous potsherds from two vessels of the Globular Amphora culture and an axe with quadrilateral section, with the polished whole surface, were found on the heap while exercising the archaeological supervision. In this section, the trench for the cable was about $80-100 \mathrm{~cm}$ wide. In its $\mathrm{N}$ profile, a large boulder was noticed surrounded by several smaller stones. Similar boulders and stones were also found on the heap, where, however, they were mixed up with a layer of bricks, mortar and roots related to modern human activity within the plot through which the cable trench was run. Due to the nature of the finds, rescue archaeological research was carried out in the vicinity of the place where archaeological artefacts and stone clusters were found. The grave of Globular Amphora culture discovered in this way was severely damaged both by the above mentioned cable trench and by the high voltage pole dug previously into the ground (Figs 2a-b; 3e-g). In addition, over the entire feature, to a depth of about $55-60 \mathrm{~cm}$ from the modern soil surface, did lie a heavily in our times processed layer related to human activity, mainly from the mid-twentieth century. Most probably already then, the ceiling of the feature has been destroyed, perhaps together with the cover of the grave.

\section{CONSTRUCTION AND DIMENSIONS}

The grave being rectangular in plan was oriented on the NW-SE axis. The stone lining of the burial chamber was constructed of various erratic boulders, the largest of which were vertically arranged. Two layers of stones have been documented in its best preserved parts, forming walls with a height of 25 to $35 \mathrm{~cm}$. The spaces between the large boulders were filled with small stones, mainly pebbles. The largest cluster of stones was preserved in the NW corner and near the SE corner of the feature (the corner itself was destroyed by the high voltage pole). In the central part of the structure there was a row of small stones arranged on the NW-SE line, 
Tabela 1. Zestawienie cech charakterystycznych grobów kultury amfor kulistych z Końskowoli, stan. 12 i z Puław-Włostowic, stan. 3

\begin{tabular}{|c|c|c|}
\hline Charakterystyka & Końskowola, stan. 12 & $\begin{array}{c}\text { Puławy-Włostowice, stan. 3, } \\
\text { obiekt 1/1977 }\end{array}$ \\
\hline Orientacja & NW-SE & NW-SE \\
\hline $\begin{array}{l}\text { Wymiary } \\
\text { (długość × szerokość) }\end{array}$ & około $300 \times 170 \mathrm{~cm}$ & $310 \times 260 \mathrm{~cm}$ \\
\hline Głębokość & $127-138 \mathrm{~cm}$ & około $60 \mathrm{~cm}$ \\
\hline $\begin{array}{l}\text { Materiał użyty } \\
\text { do budowy grobu }\end{array}$ & głazy narzutowe i otoczaki & kamienie wapienne \\
\hline Nakrywa & nie stwierdzono & nie stwierdzono \\
\hline Obstawa & $x$ & $x$ \\
\hline Bruk na dnie & $\begin{array}{c}\times \\
\text { w części SW }\end{array}$ & - \\
\hline Pochówki ludzkie & nie zachowały się & $\begin{array}{l}4 \text { (?) osobniki: mężczyzna (adultus); } \\
\text { kobieta (adultus/wczesny adultus?); } \\
\text { dziecko (infans II) i być może osobnik } \\
\text { o niemożliwej do ustalenia płci } \\
\text { w wieku adultus/senilis? }\end{array}$ \\
\hline Kości zwierzęce & brak lub nie zachowały się & $x$ \\
\hline Ślady ognia & brak lub nie zachowały się & $\begin{array}{l}\qquad \\
\text { część być może związana z późniejszym } \\
\text { osadnictwem }\end{array}$ \\
\hline Wyposażenie & $\begin{array}{l}4 \text { naczynia (naczynie } \\
\text { garnkowate w typie pucharu } \\
\text { z ornamentem sznura; } \\
\text { amfora; amfora kujawska; } \\
\text { amforka - wszystkie amfory } \\
\text { z ornamentem stempelko- } \\
\text { wym); } 1 \text { siekiera } \text { z krzemie- } \\
\text { nia czekoladowego }\end{array}$ & $\begin{array}{l}3 \text { naczynia (amfora z ornamentem } \\
\text { sznura; amfora nieornamentowana; } \\
\text { naczynie zbliżone do małej wazy); } \\
1 \text { siekiera z krzemienia czekoladowego; } \\
1 \text { siekiera z krzemienia pasiastego; } \\
\text { szable dzika (od } 3 \text { do 5) - zaginęły; } \\
\text { szydło lub ostrze kościane - zaginęło; } \\
\text { bliżej nieokreślona liczba paciorków } \\
\text { z nieokreślonego surowca - zaginęły; } \\
\text { kawałek belemnita }\end{array}$ \\
\hline Datowanie radiowęglowe & brak & $\begin{array}{l}{ }^{14} \mathrm{C}-4040 \pm 35 \text { BP }(\mathrm{Poz}-61734) \\
2619-2490 \mathrm{BC}(68,2 \%)\end{array}$ \\
\hline Literatura & niepublikowany & $\begin{array}{l}\text { Matyaszewski, Miliszkiewicz 1978; } \\
\text { Ścibior 1984, s. 101-103; Bronicki 2016, } \\
\text { s. 217-221; Niezabitowska-Wiśniewska, } \\
\text { Wiśniewski 2018; } \\
\text { Lorkiewicz-Muszyńska i in. 2018; } \\
\text { Abreu-Głowacka, Michalak 2018; } \\
\text { Rychlik i in. } 2018\end{array}$ \\
\hline
\end{tabular}

Objaśnienie: $\times$ - obecność danej cechy; - - brak obecności danej cechy.

hałdzie nad wykopem podczas nadzoru archeologicznego znaleziono bardzo liczne fragmenty ceramiki kultury amfor kulistych pochodzące z dwóch naczyń i siekierę czworościenną, gładzoną na całej powierzchni. Na tym odcinku wykop pod kabel 
Table 1. List of the characteristics of graves of Globular Amphora culture from Końskowola, site 12 and from Puławy-Włostowice, site 3

\begin{tabular}{|c|c|c|}
\hline Characteristic & Końskowola, site 12 & $\begin{array}{c}\text { Puławy-Włostowice, site } 3 \text {, } \\
\text { feature } 1 / 1977\end{array}$ \\
\hline Orientation & NW-SE & NW-SE \\
\hline $\begin{array}{l}\text { Dimensions } \\
\text { (lenght } \times \text { width) }\end{array}$ & about $300 \times 170 \mathrm{~cm}$ & $310 \times 260 \mathrm{~cm}$ \\
\hline Depth & $127-138 \mathrm{~cm}$ & about $60 \mathrm{~cm}$ \\
\hline $\begin{array}{l}\text { Material used for the } \\
\text { grave construction }\end{array}$ & erratic boulders and pebbles & limestones \\
\hline Cover & not found & not found \\
\hline Stone lining & $x$ & $x$ \\
\hline $\begin{array}{l}\text { Pavement } \\
\text { on the bottom }\end{array}$ & $\begin{array}{c}\times \\
\text { in the SW part }\end{array}$ & - \\
\hline Human burials & not preserved & $\begin{array}{l}4 \text { (?) individuals: male (adultus); } \\
\text { female (adultus/early adultus?); } \\
\text { child (infans II) and perhaps an individual } \\
\text { of unidentifiable sex in an age } \\
\text { of adultus/senilis? }\end{array}$ \\
\hline Animal bones & no or not preserved & $x$ \\
\hline Traces of fire & no or not preserved & $\begin{array}{l}\times \\
\text { a part perhaps connected with the later } \\
\text { settlement }\end{array}$ \\
\hline Burial goods & $\begin{array}{l}4 \text { vessels (a pot-like vessel } \\
\text { in type of cup with cord } \\
\text { ornament; an amphora; } \\
\text { Kuyavian amphora; small } \\
\text { amphora - all amphorae } \\
\text { with stamped ornament); } \\
1 \text { axe of chocolate flint }\end{array}$ & $\begin{array}{l}3 \text { vessels (amphora with a cord ornament; } \\
\text { not ornamented amphora; } \\
\text { a vessel similar to a small vase); } \\
1 \text { axe of chocolate flint; } 1 \text { axe of banded } \\
\text { flint; boars' tusks ( } 3 \text { to } 5 \text { ) - missing; } \\
\text { awl or bone point - missing; an unspecified } \\
\text { number of beads of an unidentified raw } \\
\text { material - missing; piece of a belemnite }\end{array}$ \\
\hline Radiocarbon dating & none & $\begin{array}{l}{ }^{14} \mathrm{C}-4040 \pm 35 \text { BP }(\mathrm{Poz}-61734) \\
2619-2490 \text { BC }(68.2 \%)\end{array}$ \\
\hline Literature & unpublished & $\begin{array}{l}\text { Matyaszewski, Miliszkiewicz 1978; Ścibior } \\
\text { 1984, pp. 101-103; Bronicki 2016, } \\
\text { pp. 217-221; Niezabitowska-Wiśniewska, } \\
\text { Wiśniewski 2018; Lorkiewicz-Muszyńska } \\
\text { et al. 2018; Abreu-Głowacka, Michalak } \\
\text { 2018; Rychlik et al. } 2018\end{array}$ \\
\hline
\end{tabular}

Explanation: $\times$ - presence of a given trait; -- absence of a given trait.

parallel to the longer sides of the burial chamber, more or less in the middle of its width and best preserved in the SE part. There, the remains of the pavement in the form of three rows of stones departing from the mentioned line at a right angles in the SW direction were also uncovered. The remains of the pavement in the form 
miał około $80-100 \mathrm{~cm}$ szerokości. W jego profilu $\mathrm{N}$ zauważono duży głaz w otoczeniu kilku mniejszych kamieni. Podobne głazy i kamienie znajdowały się także na hałdzie, gdzie jednak przemieszane były $\mathrm{z}$ warstwą cegieł, zaprawy i korzeni, związanych ze współczesną działalnością człowieka w obrębie działki, przez którą przebiegał wykop pod kabel. Ze względu na charakter znalezisk, przeprowadzono ratownicze badania archeologiczne w okolicy miejsca znalezienia zabytków archeologicznych i skupiska kamieni. Odkryty w ten sposób grób kultury amfor kulistych został silnie zniszczony zarówno przez wspomniany wykop pod kabel, jak i przez wcześniej wkopany słup wysokiego napięcia (ryc. 2a-b; 3e-g). Ponadto nad całym obiektem, do głębokości około 55-60 cm od współczesnej powierzchni gruntu zalegała silnie współcześnie przetworzona warstwa związana z działalnością gospodarczą człowieka, głównie z połowy XX w. Najprawdopodobniej już wówczas strop obiektu został zniszczony, być może łącznie z nakrywą grobu.

\section{KONSTRUKCJA I WYMIARY}

Prostokątny w rzucie grób zorientowany był na osi NW-SE. Kamienna obstawa komory grobowej skonstruowana została $\mathrm{z}$ różnej wielkości głazów narzutowych, z których największe ustawiono pionowo. W jej najlepiej zachowanych partiach zadokumentowano dwie warstwy kamieni, tworzące ściany o wysokości od 25 do $35 \mathrm{~cm}$. Przestrzenie pomiędzy dużymi głazami były wypełnione małymi kamieniami, głównie otoczakami. Największe skupisko kamieni zachowało się w narożniku NW i nieopodal narożnika SE obiektu (sam narożnik został zniszczony przez słup wysokiego napięcia). W centralnej części konstrukcji znajdował się rząd niewielkich kamieni ułożonych na linii NW-SE, równolegle do dłuższych boków komory grobowej, mniej więcej w połowie jej szerokości a najlepiej zachowany był w części SE. Tam też odsłonięto pozostałości bruku w postaci trzech rzędów kamieni odchodzących od wspomnianej linii pod kątem prostym w kierunku SW. Pozostałości bruku w postaci pojedynczych, drobnych kamieni odnotowano też na zachód od słupa wysokiego napięcia, w okolicach znalezionej in situ amfory glinianej oraz w spągu wykopu pod kabel w jego części zachodniej (ryc. 2a-d; 3a-g).

Komora grobowa miała około $300 \mathrm{~cm}$ długości i $170 \mathrm{~cm}$ szerokości. W zależności od miejsca, spąg jamy grobowej odnotowano na głębokości od 127 do $138 \mathrm{~cm}$ od współczesnej powierzchni gruntu, co też najprawdopodobniej ma związek ze znacznym stopniem zniszczenia i przekształcenia powierzchni stanowiska w czasach nowożytnych. Kamienie tworzące obstawę zagłębione były w ziemię do głębokości średnio $122 \mathrm{~cm}$. Znacznie głębiej - do około $135-138 \mathrm{~cm}$ - zalegały kamienie tworzące bruk ułożony na dnie (ryc. 3a-g).

Prawdopodobnie grobowiec z Końskowoli uznać można za dwukomorowy, choć znaczny stopień jego zniszczenia nie pozwala na jednoznaczne tego stwierdzenie. Opisany rząd kamieni zorientowany na osi NW-SE mógł być rodzajem przegrody dzielącej komorę grobową na dwie części - SW z brukiem dennym i NE bez wybrukowanego dna. Cały inwentarz grobu znaleziono w części SW obiektu (ryc. 3a-g). Niestety, ze względu na rodzaj gleby żadne kości nie zachowały się. 

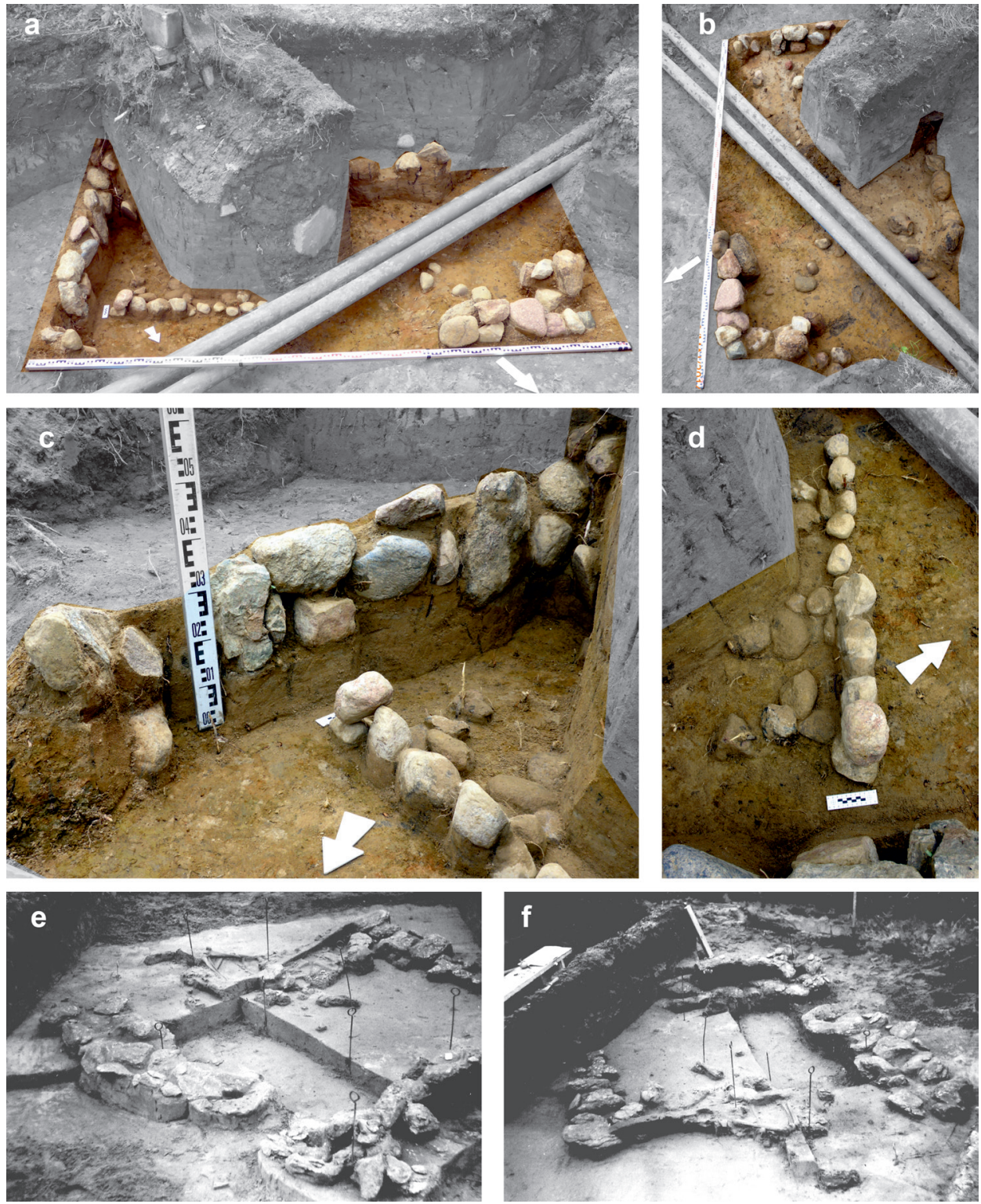

Ryc. 2. Groby kultury amfor kulistych

a-d - Końskowola, stan. 12: a-b - w pełni odsłonięta obstawa i bruk komory grobowej; c - część obstawy, przegrody i bruku w części SE komory grobowej; d - bruk i przegroda wewnątrz komory grobowej); e-f - Puławy-Włostowice, stan. 3.

Fot. T. Wiśniewski (a-d) oraz wg Niezabitowskiej-Wiśniewskiej, Wiśniewskiego 2018, ryc. 3 (e-f)

Fig. 2. Graves of Globular Amphora culture

a-d - Końskowola, site 12: a-b - fully uncovered stone lining and pavement of the burial chamber; $\mathrm{c}$ - part of the lining, partition and pavement in the SE part of the burial chamber; $\mathrm{d}$ - pavement and partition inside the burial chamber; e-f - Puławy-Włostowice, site 3.

Photo T. Wiśniewski (a-d) and after to Niezabitowska-Wiśniewska, Wiśniewski 2018, Fig. 3 (e-f) 

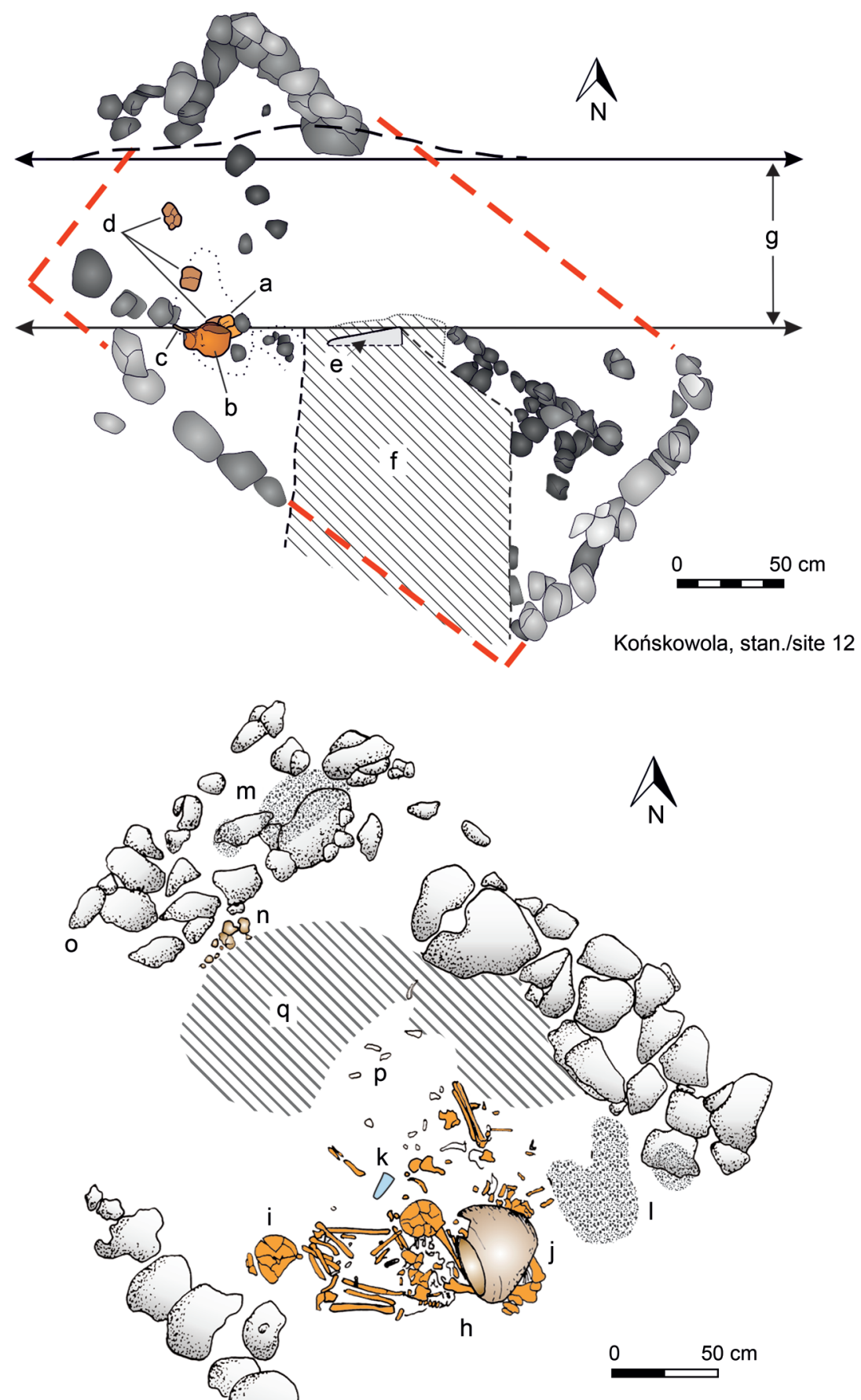

- 3

Puławy-Włostowice, stan./site 3 
of single, small stones were also observed to the west of the high voltage pole, in the vicinity of the clay amphora found in situ and in the floor of the cable trench in its western part (Figs 2a-d; 3a-g).

The burial chamber was about $300 \mathrm{~cm}$ long and $170 \mathrm{~cm}$ wide. Depending on the location, the floor of the grave pit was recorded at a depth of 127 to $138 \mathrm{~cm}$ from the contemporary surface of the ground, which is also probably associated with a significant degree of destruction and transformation of the surface of the site in modern times. The stones forming the grave lining were dug into the ground to an average depth of $122 \mathrm{~cm}$. Much deeper - to around 135-138 cm - there were occurring stones forming a pavement laid on the grave bottom (Fig. 3a-g).

Probably the grave from Końskowola can be considered as a two-chamber grave, although a significant degree of its destruction does not allow to state this unambiguously. The described row of stones oriented on the NW-SE axis could be a kind of barrier dividing the burial chamber into two parts - SW with a bottom pavement and NE without a paved bottom. The entire inventory of the grave was found in the SW part of the feature (Fig. 3a-g). Unfortunately, due to the type of soil, no bones have survived. The burial chamber was filled with layers of varying degrees of sand content, very clearly separating from the heavy, intense red clay lying outside from the walls of the stone lining.

\section{BURIAL GOODS}

Numerous fragments of two clay vessels (a pot-like vessel and a Kuyavian amphora) and a flint axe were found in the earth heap above the cable trench (Fig. 3g). In situ, in addition to individual fragments belonging to the mentioned vessels (Fig. 3c-d), another amphora was also discovered (Fig. 3b) as well as

Ryc. 3. Plany grobów kultury amfor kulistych

a-g - Końskowola, stan. 12: a - amforka znaleziona in situ; b - amfora znaleziona in situ; c - fragment amfory kujawskiej zniszczonej przez koparkę; d - fragmenty naczynia garnkowatego zniszczonego przez koparkę; e - wspornik betonowego słupa; f - część zniszczona przez słup wysokiego napięcia; g - wykop pod kabel; h-q - Puławy-Włostowice, stan. 3: h, i - szkielety dwóch osobników dorosłych (mężczyzny i kobiety); j - amfora $\mathrm{z}$ ornamentem sznura; $\mathrm{k}$ - jedna $\mathrm{z}$ siekier krzemiennych; 1 - skupisko węgla drzewnego prawdopodobnie na poziomie szczątków ludzkich; $\mathrm{m}$ - skupisko węgla drzewnego na obstawie kamiennej; $\mathrm{n}$ - fragmenty ceramiki lub kości; o - obstawa kamienna; p - kości lub fragmenty ceramiki; q - wkop, wg autorów badań z okresu rzymskiego).

Opracowała B. Niezabitowska-Wiśniewska (a-g) oraz wg Niezabitowskiej-Wiśniewskiej, Wiśniewskiego 2018, ryc. 2 (h-q)

Fig. 3. Plans of graves of Globular Amphora culture

a-g - Końskowola, site 12: a - small amphora found in situ; b - an amphora found in situ; c - fragment of a Kuyavian amphora destroyed by the excavator; $\mathrm{d}$ - fragments of a pot-like vessel damaged by the excavator; $\mathrm{e}$ - bracket of a concrete post; $\mathrm{f}$ - the part destroyed by the high voltage pole; $\mathrm{g}$ - cable trench; $\mathrm{h}-\mathrm{q}$ - Puławy-Włostowice, site 3 : $\mathrm{h}, \mathrm{i}$ - skeletons of two adult individuals (male and female); $\mathrm{j}$ - an amphora with a cord ornament; $\mathrm{k}$ - one of the flint axes; 1 - charcoal cluster probably on the level of human remains; $m$ - a charcoal cluster on a stone lining; $\mathrm{n}$ - fragments of pottery or bones; $\mathrm{o}$ - stone lining; $\mathrm{p}$ - bones or fragments of pottery; $\mathrm{q}$ - excavation, according to the authors of the research, coming from the Roman period.

Processing by B. Niezabitowska-Wiśniewska (a-g) and after to Niezabitowska-Wiśniewska, Wiśniewski 2018, Fig. 2 (h-q) 
Zasypisko komory grobowej tworzyły warstwy o różnym stopniu spiaszczenia, bardzo wyraźnie oddzielające się od ciężkiej, intensywnie rudej gliny, zalegającej na zewnątrz od ścian obstawy kamiennej.

\section{WYPOSAŻENIE}

Liczne fragmenty dwóch naczyń glinianych (naczynia garnkowatego i amfory kujawskiej) oraz siekierę krzemienną znaleziono w hałdzie ziemi nad wykopem pod kabel (ryc. 3g). In situ, oprócz pojedynczych fragmentów należących do wspomnianych naczyń (ryc.3c-d), odkryto także kolejną amforę (ryc. 3b) i naczynie miniaturowe - amforkę (ryc. 3a). Całe wyposażenie nienaruszone przez koparkę znajdowało się w części SW grobu, na pozostałościach bruku występującego na dnie komory grobowej. Nie można wykluczyć, że nie jest to pełen inwentarz. Znaczna część grobu została bowiem zniszczona przez słup wysokiego napięcia (ryc. 3e-f).

1. Naczynie garnkowate (w typie pucharu) - zniszczone przez koparkę i częściowo zrekonstruowane $\mathrm{z}$ fragmentów znalezionych na hałdzie oraz in situ $\mathrm{w}$ spągu wykopu pod kabel oraz w jego profilu południowym - z wyodrębnioną, lekko rozchyloną szyjką i największą wydętością brzuśca nieco powyżej połowy wysokości naczynia. Szyjka ornamentowana jest odciskami sznura. Na przejściu szyjki w brzusiec zachowane 3 niewielkie guzki. Powierzchnia zewnętrzna brunatna. Wymiary: wysokość $-27,8-29 \mathrm{~cm}$; średnica wylewu $-23,5-24 \mathrm{~cm}$, brzuśca $-26,2 \mathrm{~cm}$, dna - około $10 \mathrm{~cm}$ (ryc. 5a).

2. Amfora - znaleziona in situ $\mathrm{w}$ obiekcie, $\mathrm{z}$ jedną ze ścianek uszkodzoną przez koparkę - z wyodrębnioną, cylindryczną szyjką i największą wydętością brzuśca w około połowie wysokości naczynia. Dno płaskie, niewyodrębnione. W górnej partii brzuśca, przy przejściu w szyjkę, dwa poziomo przekłute uszka. Ornament stempelkowy w górnej partii brzuśca, na szyjce i na uchach. Powierzchnia zewnętrzna jasnobrązowa. Wymiary: wysokość - 18,9-19,3 cm; średnica wylewu - 8,8-9 cm, brzuśca - 16,4 cm, dna - 8,2 cm (ryc. 5c).

3. Amfora kujawska - zniszczona przez koparkę, częściowo zrekonstruowana $\mathrm{z}$ fragmentów znalezionych na hałdzie i jednego znalezionego in situ w profilu południowym wykopu pod kabel - z niską, prawdopodobnie cylindryczną szyjką, kulistym zarysem brzuśca i płaskim dnem. Na barku brzuśca przy przejściu w szyjkę dwa, poziomo przekłute uszka (pierwotnie prawdopodobnie cztery). W górnej partii brzuśca, na szyjce i uszkach ornament stempelkowy. Powierzchnia zewnętrzna - plamista, brunatno-pomarańczowa. Wymiary: wysokość - około 19,5cm; średnica wylewu - około 12,4 cm, brzuśca - około 19,2 cm, dna - 9,4-10 cm (ryc. 5d).

4. Amforka - znaleziona in situ w obiekcie, silnie zniszczona - ze słabo zaznaczoną, dość wysoką, cylindryczną szyjką i lekko wypukłym dnem. W górnej partii brzuśca dwa niewielkie, poziomo przekłute uszka. Na szyjce ornament stempelkowy. Powierzchnia zewnętrzna - plamista, pomarańczowo-brunatna. Wymiary: wysokość - 9,8cm; średnica wylewu - 7,5 cm, brzuśca - 9,2 cm (ryc. 5b).

5. Siekiera - znaleziona na hałdzie nad wykopem pod kabel - płaska, czworościenna z krzemienia czekoladowego, gładzona na całej powierzchni. Wymiary: długość - 15,6 cm; szerokość obucha $-3 \mathrm{~cm}$, ostrza $-5,2 \mathrm{~cm}$, grubość - 2,5 cm (ryc. 6a). 
a miniature amphora (Fig. 3a). All grave goods intact by the excavator were located in the SW part of the grave, on the remains of the pavement found at the bottom of the burial chamber. It cannot be ruled out that this is not a full grave inventory. A considerable part of the grave was destroyed by the high voltage pole (Fig. 3e-f).

1. Pot-shaped vessel (in the cup type) - destroyed by the excavator and partially reconstructed from fragments found on the heap and in situ in the base of the cable trench and in its southern profile - with a separated, slightly open neck and the greatest body bulge slightly above half the height of the vessel. The neck is ornamented with cord impressions. On the transition from the neck to the body three small knobs have been preserved. The outer surface is brown. Dimensions: height $-27.8-29 \mathrm{~cm}$; diameter of the rim $-23.5-24 \mathrm{~cm}$, of the body $-26.2 \mathrm{~cm}$, of the base - about $10 \mathrm{~cm}$ (Fig. 5a).

2. Amphora - found in situ in the feature, with one of the walls damaged by the excavator - with a separate, cylindrical neck and the greatest body diameter in about half the height of the vessel. Flat base, not separated. In the upper part of the body, at the transition to the neck, there are two horizontally pierced small handles. A stamped ornament in the upper part of the body, on the neck and on the handles. Outer surface light brown. Dimensions: height $-18.9-19.3 \mathrm{~cm}$; diameter of the rim $-8.8-9 \mathrm{~cm}$, of the body $-16.4 \mathrm{~cm}$, of the base $-8.2 \mathrm{~cm}$ (Fig. $5 \mathrm{c}$ ).

3. Kuyavian amphora - destroyed by the excavator, partially reconstructed from fragments found on the heap and one piece found in situ in the southern profile of the cable trench - with a low, probably cylindrical neck, a spherical body contour and a flat base. On the shoulder of the body, at the transition to the neck, two horizontally pierced small handles (initially probably four). In the upper part of the body, on the neck and the handles a stamped ornament. Outer surface - patchy, brownish-orange. Dimensions: height - about $19.5 \mathrm{~cm}$; diameter of the rim - about $12.4 \mathrm{~cm}$, of the body - about $19.2 \mathrm{~cm}$, of the base $-9.4-10 \mathrm{~cm}$ (Fig. $5 \mathrm{~d}$ ).

4. Small amphora - found in situ in the feature, heavily damaged - with a poorly pronounced, quite high, cylindrical neck and slightly convex base. Two small, horizontally pierced handles in the upper part of the body. A stamped ornament on the neck. Outer surface - spotty, orange-brown. Dimensions: height $-9.8 \mathrm{~cm}$; diameter of the rim $-7.5 \mathrm{~cm}$, body $-9.2 \mathrm{~cm}$ (Fig. $5 \mathrm{~b}$ ).

5. Axe - found on the heap above the cable excavation - flat, with quadrilateral section, of chocolate flint, polished on the whole surface. Dimensions: length $-15,6 \mathrm{~cm}$; width of the butt $-3 \mathrm{~cm}$, of the cutting edge $-5.2 \mathrm{~cm}$, thickness $-2.5 \mathrm{~cm}$ (Fig. 6a).

\section{ANALYSIS OF GRAVES FROM PUŁAWY-WŁOSTOWICE AND KOŃSKOWOLA}

The graves of Globular Amphora culture from Puławy-Włostowice and Końskowola, apart from their location in a similar landscape zone, have much more common traits. Among them is the presence of a stone lining and the similar dimensions of the burial chamber (Fig. 3). In both cases, there is no cover, which, 

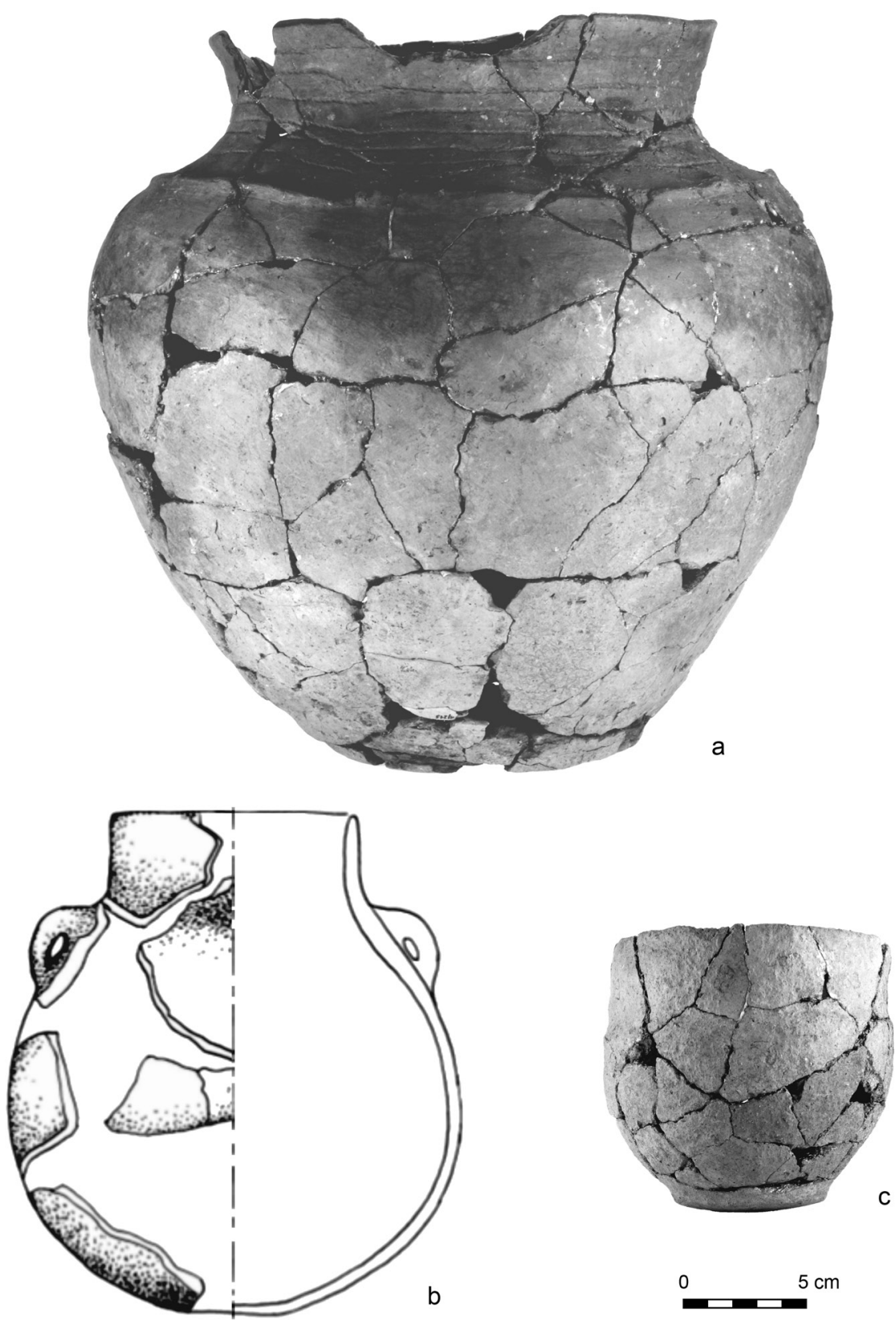

Ryc. 4. Naczynia z grobu kultury amfor kulistych z Puław-Włostowic, stan. 3

$\mathrm{a}$ - amfora $\mathrm{z}$ ornamentem sznura; $\mathrm{b}$ - amfora; $\mathrm{c}$ - naczynie zbliżone do małej wazy.

Wg Niezabitowskiej-Wiśniewskiej, Wiśniewskiego 2018, ryc. 4; 5; tabl. I

Fig. 4. Vessels from the grave of the Globular Amphora culture from Puławy-Włostowice, site 3 $\mathrm{a}$ - an amphora with a cord ornament; b - amphora; $\mathrm{c}$ - a vessel similar to a small vase.

After to Niezabitowska-Wiśniewska, Wiśniewski 2018, Figs 4; 5; Pl. I 
however, may be caused by a significant destruction of these graves - in Puławy-Włostowice by the later prehistoric settlement ${ }^{1}$, and in Końskowola by the modern settlement. A. Bronicki has included the grave from Puławy-Włostowice in the sixth group of burial structures in the type of Nałęczów - with stone lining without top pavement and laid on the bottom, including to this group yet the grave 1 from site 4 in Klementowice, Puławy district (Bronicki 2016, pp. 229, 232; cf. Halicki 1970, pp. 303-305). Adopting the criteria for the division of graves proposed by this author, the feature from Końskowola belongs to the fifth group of burial structures in the Nałęczów type - with a stone lining and a paved bottom (Bronicki 2016, pp. 213-232). This group is also represented by grave 7 from site 4 in Klementowice, Puławy district (Kowalczyk 1968, pp.372-374; Halicki 1970, pp.309-311; Bronicki 2016, pp. 100-102, 231) and the grave from cemetery $\mathrm{H}$ in the Las Stocki, Puławy district (Ścibior 1984, pp. 57-60; Bronicki 2016, pp. 142-143, 231-232). The last one is also linked with grave from Końskowola by approximate dimensions of a rectangular but relatively narrow grave lining $(350 \times 190 \mathrm{~cm})$ and the presence of two chambers - the western and eastern ones ${ }^{2}$. They were created by placing a wall/ partition in the middle of the length of the burial chamber made of loosely arranged stones. The bottom of the eastern chamber, in its western and central part, was paved and probably three dead with grave goods were placed on it. Two or three cows were deposited in the not paved western chamber. The described structure of the grave in the Las Stocki allows for cautious assumption that a deceased or several deceased were also placed in a two-chamber grave from Końskowola in the part with stone pavement. This is also indicated by the placement of the burial goods there. The part devoid of pavement could be intended for animal burials. By accepting this hypothesis, it can be supposed that the row of stones running through the middle separated the paved zone intended for people from the zone intended for animals. Unfortunately, as already mentioned, no bone remains have survived due to the sandy backfill of the burial chamber. In addition, unlike the funerary chamber from Las Stocki, where the partition was placed parallel to the shorter sides of the stone lining, the grave chamber in Końskowola was separated by a row of stones arranged parallel to the longer sides of the lining.

Clear differences can be, however, observed with reference to the material used for the construction of grave chambers of the features from Puławy-Włostowice

${ }^{1}$ According to the authors of the study, this grave was destroyed by an excavation from the Roman period. From that time, supposed were also to come two hearths, for which construction were used the stones from the violated parts of the Globular Amphora culture grave, then they were placed on its lining (Matyaszewski, Miliszkiewicz 1978; cf. Bronicki 2016, pp. 217; Niezabitowska-Wiśniewska, Wiśniewski 2018). On doubts about the correct identification of materials from the Roman period, see also: Niezabitowska-Wiśniewska 2018, pp. 41-44, 103, Table 14:62-64.

${ }^{2}$ In the Nałęczów subgroup of the Globular Amphora culture, the presence of two chambers was also recorded in the tomb 3 at the site 4 in Klementowice (Halicki 1970, pp. 305-309; Bronicki 2016, pp. 97-100) and in the grave from the site 2 in Stok, Puławy district (Kowalczyk 1953, pp. 38-47; Nosek 1967, pp. 238-240; Bronicki 2016, pp. 196-202). However, in both cases the remaining elements of the graves' construction deviate from the situation observed in Końskowola. In the first lacking is the stone lining, in the second there was probably also a cover (cf. Bronicki 2016, Table 6). 
Ryc. 5. Wyposażenie grobu kultury amfor kulistych z Końskowoli, stan. 12 a - naczynie garnkowate (w typie pucharu); b - amforka; c - amfora, d - amfora kujawska.

Rys. Niezabitowska-Wiśniewska

Fig. 5. The burial goods of the grave of the Globular Amphora culture from Końskowola, site 12 $\mathrm{a}$ - a pot-like vessel (in the type of a cup); $\mathrm{b}$ - small amphora; $\mathrm{c}$ - amphora; $\mathrm{d}$ - Kuyavian amphora.

Drawing B. Niezabitowska-Wiśniewska

\section{ANALIZA GROBÓW Z PUŁAW-WŁOSTOWIC I KOŃSKOWOLI}

Groby kultury amfor kulistych z Puław-Włostowic i Końskowoli, oprócz położenia w podobnej strefie krajobrazowej, mają znacznie więcej cech wspólnych. Wśród nich jest obecność obstawy i podobne wymiary komory grobowej (ryc. 3). W obu przypadkach brak jest nakrywy, co jednak może być spowodowane znacznym zniszczeniem tych grobów - w Puławach-Włostowicach przez późniejsze osadnictwo pradziejowe ${ }^{1}$, a w Końskowoli przez osadnictwo nowożytne. A. Bronicki grób z Puław-Włostowic zaliczył do szóstej grupy konstrukcji grobowych w typie nałęczowskim - z obstawą bez bruku stropowego i ułożonego na dnie, włączając do niej jeszcze grób 1 ze stanowiska $4 \mathrm{w}$ Klementowicach, pow. puławski (Bronicki 2016, s. 229, 232; por. Halicki 1970, s. 303-305). Przyjmując kryteria podziału grobów zaproponowane przez tego autora, obiekt z Końskowoli zaliczyć należy do piątej grupy konstrukcji grobowych $\mathrm{w}$ typie nałęczowskim $-\mathrm{z}$ obstawą i brukowanym dnem (Bronicki 2016, s. 213-232). Grupę tę reprezentuje również grób 7 ze stanowiska 4 w Klementowicach, pow. puławski (Kowalczyk 1968, s. 372-374; Halicki 1970, s. 309-311; Bronicki 2016, s. 100-102, 231) i grób z cmentarzyska H w Lesie Stockim, pow. puławski (Ścibior 1984, s. 57-60; Bronicki 2016, s. 142-143, 231-232). Ten ostatni z grobem z Końskowoli łączą również zbliżone wymiary prostokątnej, ale stosunkowo wąskiej obstawy grobu $(350 \times 190 \mathrm{~cm})$ oraz obecność dwóch komór - zachodniej i wschodniej². Powstały one przez umieszczenie $\mathrm{w}$ połowie długości komory grobowej ścianki/przegrody z luźno ułożonych kamieni. Dno komory wschodniej, w jej zachodniej i środkowej części, zostało

${ }^{1}$ Według autorów badań grób ten zniszczony został przez wkop z okresu rzymskiego. Z tego też czasu miały pochodzić dwa paleniska, do których budowy wykorzystano kamienie z naruszonych partii grobu kultury amfor kulistych, umieszczone następnie na jego obstawie (Matyaszewski, Miliszkiewicz 1978; por. Bronicki 2016, s. 217; Niezabitowska-Wiśniewska, Wiśniewski 2018). O wątpliwościach co do poprawnej identyfikacji materiałów z okresu rzymskiego zob. też: Niezabitowska-Wiśniewska 2018, s. 41-44, 103, tabela 14:62-64.

${ }^{2}$ W podgrupie nałęczowskiej kultury amfor kulistych obecność dwóch komór odnotowano również w grobie 3 na stan. 4 w Klementowicach (Halicki 1970, s. 305-309; Bronicki 2016, s. 97-100) oraz w grobie ze stan. 2 w Stoku, pow. puławski (Kowalczyk 1953, s. 38-47; Nosek 1967, s. 238-240; Bronicki 2016, s. 196-202). Jednak w obu przypadkach pozostałe elementy konstrukcji grobów odbiegają od sytuacji zaobserwowanej w Końskowoli. W pierwszym brak jest obstawy, w drugim prawdopodobnie istniała również nakrywa (por. Bronicki 2016, tabela 6). 

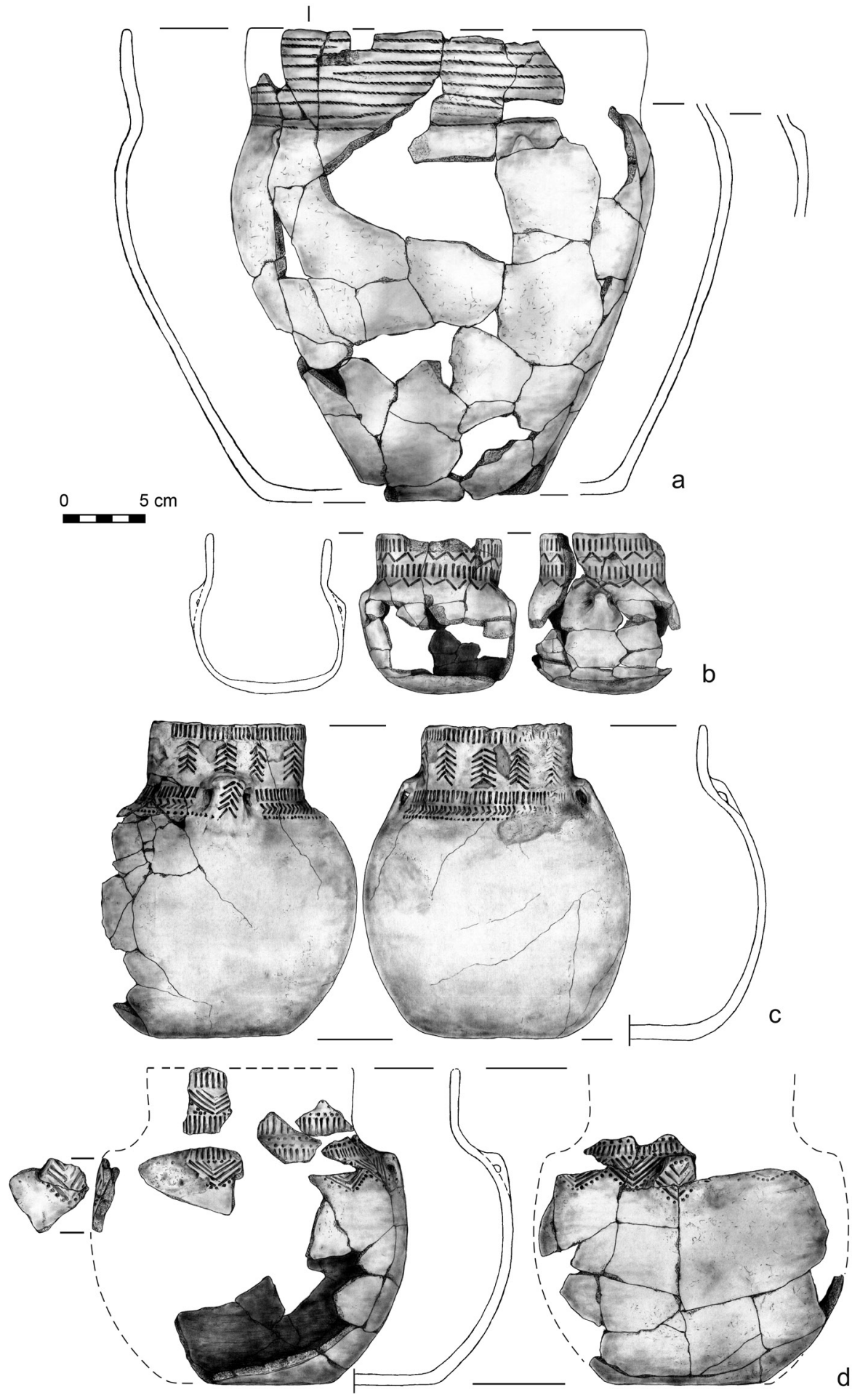
wybrukowane i umieszczono na nim najprawdopodobniej trzech zmarłych wraz $\mathrm{z}$ wyposażeniem. W pozbawionej bruku komorze zachodniej złożono dwie lub trzy krowy. Opisana konstrukcja grobu w Lesie Stockim pozwala ostrożnie zakładać, że również w dwukomorowym grobie z Końskowoli w części z brukiem kamiennym złożono zmarłego lub zmarłych. Wskazuje na to także umieszczenie tam wyposażenia grobowego. Część pozbawiona bruku mogła być przeznaczona na pochówki zwierzęce. Przyjmując tę hipotezę można założyć, że biegnący przez środek rząd kamieni oddzielał wybrukowaną strefę przeznaczoną dla ludzi od strefy przeznaczonej dla zwierząt. Niestety, jak już wspomniano, ze względu na piaszczyste zasypisko komory grobowej żadne szczątki kostne nie zachowały się. Ponadto w odróżnieniu od komory grobowej z Lasu Stockiego, gdzie przegrodę umieszczono równolegle do krótszych boków obstawy, komora grobowa w Końskowoli została przedzielona rzędem kamieni ułożonym równolegle do dłuższych boków obstawy.

Wyraźne różnice zaobserwować można natomiast w odniesieniu do materiału użytego do budowy komór grobowych obiektów z Puław-Włostowic i Końskowoli. W Puławach-Włostowicach zbudowano ją z jednej warstwy różnej wielkości kamieni wapiennych - według autorów badań o łącznej wadze około $200 \mathrm{~kg}$ (Matyaszewski, Miliszkiewicz 1978), co odzwierciedla kanon znany ze zdecydowanej większości stanowisk podgrupy nałęczowskiej (ryc. 2e-f). Grób z Końskowoli zbudowany był natomiast $\mathrm{z}$ kamieni narzutowych różnej wielkości i otoczaków, przy czym największych głazów użyto do budowy obstawy (ryc. 2a-d). Użycie podobnego budulca, obok płyt z piaskowców i zlepieńców muszlowych, powszechnie jest notowane $\mathrm{w}$ grupie wschodniolubelskiej kultury amfor kulistych, gdzie jednak dominującym typem grobu jest grób skrzyniowy (por. Bronicki 2016, s. 228-229 - tam dalsza literatura). Podobną, skrzyniową konstrukcję, do której budowy wykorzystywano głazy granitowe lub monolity trzeciorzędowego piaskowca kwarcytowego, mają też groby z obszaru północnej i północno-wschodniej, nizinnej części Lubelszczyzny, w tym np. z Branicy Suchowolskiej, pow. radzyński; Okalewa, pow. parczewski (Nosek [1950] 1954/1955, s. 57-58, 80; tenże 1967, s. 241-242); Nadrybia-Dworu, pow. łęczyński (Zakościelna 2000); Rudna, pow. parczewski (Ścibior 1985b; 1986); Wytyczna i Wytyczna-Kolonii, pow. włodawski (Nosek 1967, s. 244-245)33. W obu wymienionych strefach ze skał tych formowano jednak monolityczne płyty wykorzystywane następnie do budowy ścian i nakryw grobów. Ponadto wymiary zbudowanych w ten sposób grobów skrzyniowych o długościach oscylujących od 150 do $250 \mathrm{~cm}$ i szerokościach mieszczących się w przedziale od 70 do $150 \mathrm{~cm}$ znacznie różnią się od wymiarów grobów typu nałęczowskiego o długościach $\mathrm{z}$ reguły przekraczających $200 \mathrm{~cm}$ i w skrajnych przypadkach osiągających nawet $520 \mathrm{~cm}$ (Bronicki 2016, s. 228-232, tabele 4; 5). Z całą pewnością więc zarówno grób z Puław-Włostowic, jak i grób z Końskowoli reprezentują typ nałęczowski grobów kultury amfor kulistych. W pierwszym przypadku do jego budowy użyto materiału powszechnie występującego na Płaskowyżu Nałęczowskim, oddalonym od miejsca usytuowania grobu jedynie o około $200 \mathrm{~m}$ (por. Ścibior 1991, s. 60). W przypadku

${ }^{3}$ Por.: Kozak-Zychman, Szeliga 2004; Libera, Taras 2011, s. 40-43. 
and Końskowola. In Puławy-Włostowice, they were built of one layer of various size limestones - according to the authors of the study, with a total weight of about $200 \mathrm{~kg}$ (Matyaszewski, Miliszkiewicz 1978), which reflect a canon known from the vast majority of the sites of the Nałęczów subgroup (Fig. 2e-f). The grave from Końskowola was built of erratic stones of various sizes and pebbles, the largest boulders were used for construction of the lining (Fig. 2a-d). The use of similar building material, along with sandstone slabs and shell conglomerates, is commonly noted in the Eastern-Lublin group of the Globular Amphora culture, where the dominant type of the grave is the box burial (cf. Bronicki 2016, pp. 228-229 - there further literature). A similar box structure, for which granite boulders or tertiary quartzite sandstone monoliths were used, also are to be found in the graves from the northern and north-eastern part of the lowland part of the Lublin region, including, for example, Branica Suchowolska, Radzyń district; Okalew, Parczew district (Nosek [1950] 1954/1955, pp. 57-58, 80; idem 1967, pp. 241-242); Nadrybie-Dwór, Łęczna district (Zakościelna 2000); Rudno, Parczew district (Ścibior 1985b; 1986); Wytyczno and Wytyczno-Kolonia, Włodawa district (Nosek 1967, pp. 244-245) ${ }^{3}$. In both these mentioned zones, however, from these rocks formed were monolithic slabs which were used then to build walls and covers of graves. In addition, the dimensions of box graves built in this way with lengths oscillating from 150 to $250 \mathrm{~cm}$ and widths within range from 70 to $150 \mathrm{~cm}$ are significantly different from the dimensions of the Nałęczów type graves with lengths usually exceeding $200 \mathrm{~cm}$ and in extreme cases even up to $520 \mathrm{~cm}$ (Bronicki 2016, pp. 228-232, Tables 4; 5). Certainly, both the grave from Puławy-Włostowice, as well as the grave from Końskowola, represent the Nałęczów type of graves of the Globular Amphora culture. In the first case, for its construction was used a material commonly found on the Nałęczów Plateau, away from the place where the grave was situated only about $200 \mathrm{~m}$ (cf.: Ścibior 1991, p. 60). In the case of the grave from Końskowola, the idea of the construction of the grave, known mainly from the nearby Nałęczów Plateau, was adopted, but for its construction was used material occurring en masse in the immediate vicinity. In this case, were not used monolithic rock blocks, but stones with sizes similar to the size of limestone rocks used for the construction of the Nałęczów type tombs. Most likely, erratic rocks ${ }^{4}$ could have been occurring superficially in the area of the Kurówka Valley or come from outcrops of the boulder clays from the Southern and Middle Polish Glaciations and their slope washes and residues.

It seems, that the closest analogies to the feature from Końskowola in terms of construction and material used there, are to be found outside the Lublin region in two graves from the locality Rębków-Parcele ${ }^{5}$, Garwolin district, discovered in 1937 (Salewicz 1937) and located on the Garwolin Plain. For construction of their linings

${ }^{3}$ Cf.: Kozak-Zychman, Szeliga 2004; Libera, Taras 2011, pp. 40-43.

${ }^{4}$ Occasionally, individual granite boulders were also used to construct Nałęczów type tombs. Two such boulders were placed, for example, in the cover of the grave II from the site 1 in Klementowice, where they were only accompanying the limestones used both for the construction of the cover and the stone lining of this grave (Uzarowiczowa 1968; Bronicki 2016, p. 74).

5 At present Parcele-Rębków, Garwolin commune, Garwolin district, Mazovian voivodeship. 
grobu z Końskowoli zaadaptowano ideę konstrukcji grobu znaną głównie z pobliskiego Płaskowyżu Nałęczowskiego, ale do jego budowy wykorzystano materiał masowo występujący w najbliższej okolicy. Użyto przy tym nie monolitycznych bloków skalnych, a kamieni o wielkościach zbliżonych do wielkości skał wapiennych wykorzystywanych do budowy grobowców typu nałęczowskiego. Najprawdopodobniej skały narzutowe ${ }^{4}$ mogły zalegać powierzchniowo w rejonie doliny Kurówki lub pochodzić z wychodni glin zlodowaceń południowo- i środkowopolskich oraz ich deluwiów i rezyduów.

Obiekt z Końskowoli najbliższe analogie pod względem konstrukcji i materiału użytego do budowy wydaje się znajdować poza Lubelszczyzną w dwóch grobach z miejscowości Rębków-Parcele ${ }^{5}$, pow. garwoliński, odkrytych w 1937 r. (Salewicz 1937) i położonych na Równinie Garwolińskiej. Do budowy ich obstaw użyto „średniej wielkości głazów narzutowych” (grób I) ${ }^{6}$ lub „większych i mniejszych okrąglaków" (grób II) (Nosek [1950] 1954/1955, s. 91-92; tenże 1967, s. 135-140). W zniszczonym grobie I miało też znajdować się brukowane płaskimi, mniejszymi kamieniami dno, nakrywa w postaci bruku oraz wewnątrz komory grobowej poprzeczna przegroda dzieląca ją na dwie równe części. Choć oba opisywane groby w porównaniu $\mathrm{z}$ obiektem $\mathrm{z}$ Końskowoli zawierały znacznie bogatsze wyposażenie, w jego skład wchodziły także naczynia określone jako amfory i puchary z poziomymi odciskami sznura na szyjkach. Znalezione tam siekiery wykonane zostały z krzemienia pasiastego, a wióry z krzemienia czekoladowego. Wszystkie opisywane tu groby miały też bardzo podobne wymiary ${ }^{7}$ (Nosek [1950] 1954/1955, s. 91-100, 119; tenże 1967, s. 135-140). Konstrukcję zbliżoną do grobu z Końskowoli miały też prawdopodobnie obiekty z Małoszewa (grób 2), pow. płocki i Dziekanowa Niemieckiego ${ }^{8}$ (stan. 1; grób odkryty w 1938 r.), pow. warszawski oraz być może zniszczone groby z Grodkowa, pow. płocki i Wólki Zatorskiej, pow. pułtuski (Nosek 1967, s. 345; Kempisty 1971, s. 14-18, 25).

Niestety, niemożliwe jest przeprowadzenie analizy porównawczej grobów z Puław-Włostowic i Końskowoli pod względem liczby pochówków ludzkich i zwierzęcych czy orientacji, ułożenia oraz płci i wieku pochowanych tam zmarłych, $z$ uwagi na brak zachowanych szczątków kostnych w grobie z drugiej z tych miejscowości.

${ }^{4}$ Sporadycznie pojedynczych głazów granitowych używano również do budowy grobowców typu nałęczowskiego. Dwa takie głazy umieszczono na przykład w pokrywie grobu II ze stanowiska 1 $\mathrm{w}$ Klementowicach, przy czym jedynie towarzyszyły one kamieniom wapiennym wykorzystanym zarówno do budowy pokrywy, jak i obstawy tego grobu (Uzarowiczowa 1968; Bronicki 2016, s. 74).

${ }^{5}$ Obecnie Parcele Rębków, gm. Garwolin, pow. garwoliński, woj. mazowieckie.

${ }^{6}$ Według E. Kempisty (1971, s. 13, zestawienie 1) grób I był grobem skrzynkowym. Opis ten ma prawdopodobnie związek z informacją odkrywcy grobu zrelacjonowaną przez K. Salewicza (1937, s. 80) i następnie przez S. Noska ([1950] 1954/1955, s. 91), zgodnie z którą miał on mieć kształt prostokątnej skrzyni. Wzmianka o zbudowaniu grobu ze średniej wielkości głazów narzutowych i podane wymiary (około $300 \times 150 \mathrm{~cm}$ ) wydają się jednak wskazywać, że mamy tu do czynienia z obiektem o konstrukcji zbliżonej do grobów typu nałęczowskiego.

7 Rębków-Parcele, grób I - około $300 \times 150$ cm; grób II - około $325 \times 150$ cm; Końskowola - około $300 \times 170 \mathrm{~cm}$.

${ }^{8}$ Obecnie Dziekanów Leśny, gm. Łomianki, pow. warszawski, woj. mazowieckie. 
were used "medium sized erratic boulders" (grave I) ${ }^{6}$ or "larger and smaller round logs” (grave II) (Nosek [1950] 1954/1955, pp. 91-92; idem 1967, pp. 135-140). In the destroyed grave I, presumably also had to be a bottom paved with flat, small stones, a cover in the form of pavement as well as inside the burial chamber a transverse partition dividing it into two equal parts. Although both described graves in comparison with the feature from Końskowola contained much richer burial goods, it also included vessels identified as amphorae and cups with horizontal cord impressions on the necks. The axes found there were made of banded flint and the blades of chocolate flint. All graves described here had also very similar dimensions $^{7}$ (Nosek [1950] 1954/1955, pp. 91-100, 119; idem 1967, pp. 135-140). A similar structure to the grave from Końskowola had probably also the features from Małoszewo (grave 2), Płock district and Dziekanów Niemiecki ${ }^{8}$ (site 1, grave discovered in 1938), Warsaw district and perhaps the destroyed graves from Grodkowo, Płock district and Wólka Zatorska, Pułtusk district (Nosek 1967, pp. 345; Kempisty 1971, pp. 14-18, 25).

Unfortunately, it is impossible to carry out a comparative analysis of graves from Puławy-Włostowice and Końskowola in terms of the number of human and animal burials or the orientation, arrangement as well as sex and age of the dead buried there, due to the lack of preserved bone remains in the grave from the second of these two localities. However, it cannot be ruled out that more than one deceased person were deposited in the grave from Końskowola, similarly as in the case of the grave from Puławy-Włostowice (Table 1). In the last grave, most probably were also found traces of lighting fire in the burial chamber' ${ }^{9}$ They were not recorded in the grave of Końskowola, what, however, may be related to its significant destruction in modern times.

Far more similarities show instead the burial goods of the graves from Puławy-Włostowice and Końskowola. In both of them large vessels ornamented with cord impressions on the neck were discovered, in the first of these features an amphora with a strongly bulging, globular body (Fig. 4a), in the second one - a pot-shaped vessel in the type of a cup (Fig. 5a). The most interesting, however, is the fact of finding tetrahedral axes of chocolate flint in both analysed graves (Fig. 6). In the feature from Puławy-Włostowice, such an axe appeared accompanied by a specimen of banded flint; in the grave from Końskowola - solo. It should also be emphasized that in the current literature, both axes from Puławy-Włostowice were described as

${ }^{6}$ According to E. Kempisty (1971, p. 13, list 1), grave I was a box grave. This description is probably related to the information obtained from the discoverer of the grave reported by K. Salewicz (1937, p. 80) and then by S. Nosek ([1950] 1954/1955, p. 91), according to which it was supposed to have the shape of a rectangular box. The mention of constructing a grave of medium size erratic boulders and the given dimensions (about $300 \times 150 \mathrm{~cm}$ ), however, seems to indicate that we have to do here with a feature with a structure close to that of the graves of Nałęczów type.

7 Rębków-Parcele, grave I - ca $300 \times 150 \mathrm{~cm}$; grave II - ca $325 \times 150 \mathrm{~cm}$; Końskowola - ca $300 \times 170 \mathrm{~cm}$.

8 At present Dziekanów Leśny, Łomianki commune, Warsaw district, Mazovian voivodeship.

${ }^{9}$ On problems with the identification of clusters of charcoals in the burial chamber from Puławy-Włostowice, see: Niezabitowska-Wiśniewska, Wiśniewski 2018, pp. 265-267. 
Ryc. 6. Siekiery z krzemienia czekoladowego

a - Końskowola, stan. 12; b - Puławy-Włostowice, stan. 3.

Rys. i fot. T. Wiśniewski (a) oraz wg Niezabitowskej-Wiśniewskiej, Wiśniewskiego, 2018, Fig. 6:1; tabl. III 5 (b)

Fig. 6. Axes of chocolate flint

a - Końskowola, site 12; b - Puławy-Włostowice, site 3.

Drawing and photo by T. Wiśniewski (a) and after to Niezabitowska-Wiśniewska, Wiśniewski 2018, Fig. 6:1; Pl. III 5 (b)

Nie można jednak wykluczyć, że w grobowcu z Końskowoli złożono więcej niż jednego zmarłego, podobnie jak w przypadku grobu z Puław-Włostowic (tabela 1). W ostatnim z grobów najprawdopodobniej odkryto też ślady palenia ognia w komorze grobowej ${ }^{9}$. Nie odnotowano ich natomiast w grobie z Końskowoli, co jednak może mieć związek ze znacznym jego zniszczeniem w czasach nowożytnych.

Daleko więcej podobieństw wykazuje natomiast wyposażenie grobów z Puław-Włostowic i Końskowoli. W obu odkryto duże naczynia ornamentowane odciskami sznura na szyjce, przy czym w pierwszym $\mathrm{z}$ obiektów wystąpiła amfora $\mathrm{z}$ silnie wydętym, baniastym brzuścem (ryc. 4a), w drugim - naczynie garnkowate w typie pucharu (ryc. 5a). Najciekawszy jest jednak fakt znalezienia w obu analizowanych grobach siekier czworościennych z krzemienia czekoladowego (ryc. 6). W obiekcie z Puław-Włostowic siekiera taka wystąpiła wraz z okazem z krzemienia pasiastego; w grobie z Końskowoli samodzielnie. Podkreślić należy również, że w dotychczasowej literaturze obie siekiery z Puław-Włostowic opisywane były jako wykonane z krzemienia pasiatego (Ścibior 1984, s. 103; Bronicki 2016, s. 221; por. Niezabitowska-Wiśniewska, Wiśniewski 2018, s. 268-269, ryc. 6:1, tabl. III 5).

Według najnowszego zestawienia opublikowanego przez A. Bronickiego, w 20 grobach typu nałęczowskiego odkryto 35 siekier, przy czym $30 \mathrm{z}$ nich wykonano $\mathrm{z}$ krzemienia pasiastego ${ }^{10}, 3 \mathrm{z}$ krzemienia w typie wołyńskiego, surowiec pozostałych nie został określony. Tym samym autor ten nie wymienia żadnego okazu z krzemienia czekoladowego (Bronicki 2016, s. 245-248, tabela 12). Z podgrupy nałęczowskiej kultury amfor kulistych znamy jedynie wióry, wiórki, wióroodłupki i nieliczne narzędzia wiórowe (trapezy, drapacz na sierpaku i półtylczak) wykonane z tego surowca ${ }^{11}$ oraz pojedyncze odłupki (Bronicki 2016, s. 246-249, tabela 12). Siekier z krzemienia czekoladowego nie odkryto dotąd również wśród inwentarzy innych typów grobów kultury amfor kulistych znanych z Lubelszczyzny (por. Nosek 1967, s. 323-324, 364; Bronicki 2016, s. 239-241).

Datowanie grobu w Puławach-Włostowicach oprzeć można na oznaczeniu ${ }^{14} \mathrm{C}(4040 \pm 35 \mathrm{BP}) \mathrm{z}$ kości ludzkiej, która po przeliczeniu na wiek kalendarzowy

${ }^{9}$ O problemach z identyfikacją skupisk węgli drzewnych w komorze grobowej z Puław-Włostowic zob.: Niezabitowska-Wiśniewska, Wiśniewski 2018, s. 265-267.

${ }_{10}$ A. Bronicki do zbioru tego zaliczył również dwa okazy z Puław-Włostowic, oba uznając za wykonane $\mathrm{z}$ krzemienia pasiastego. W rzeczywistości tylko jedna $\mathrm{z}$ siekier zrobiona jest $\mathrm{z}$ tego surowca.

${ }^{11}$ Według A. Bronickiego w dwunastu grobach tej podgrupy odkryto łącznie 22 wyroby wiórowe, z których 13 wykonano z krzemienia czekoladowego (Bronicki 2016, s. 248). 

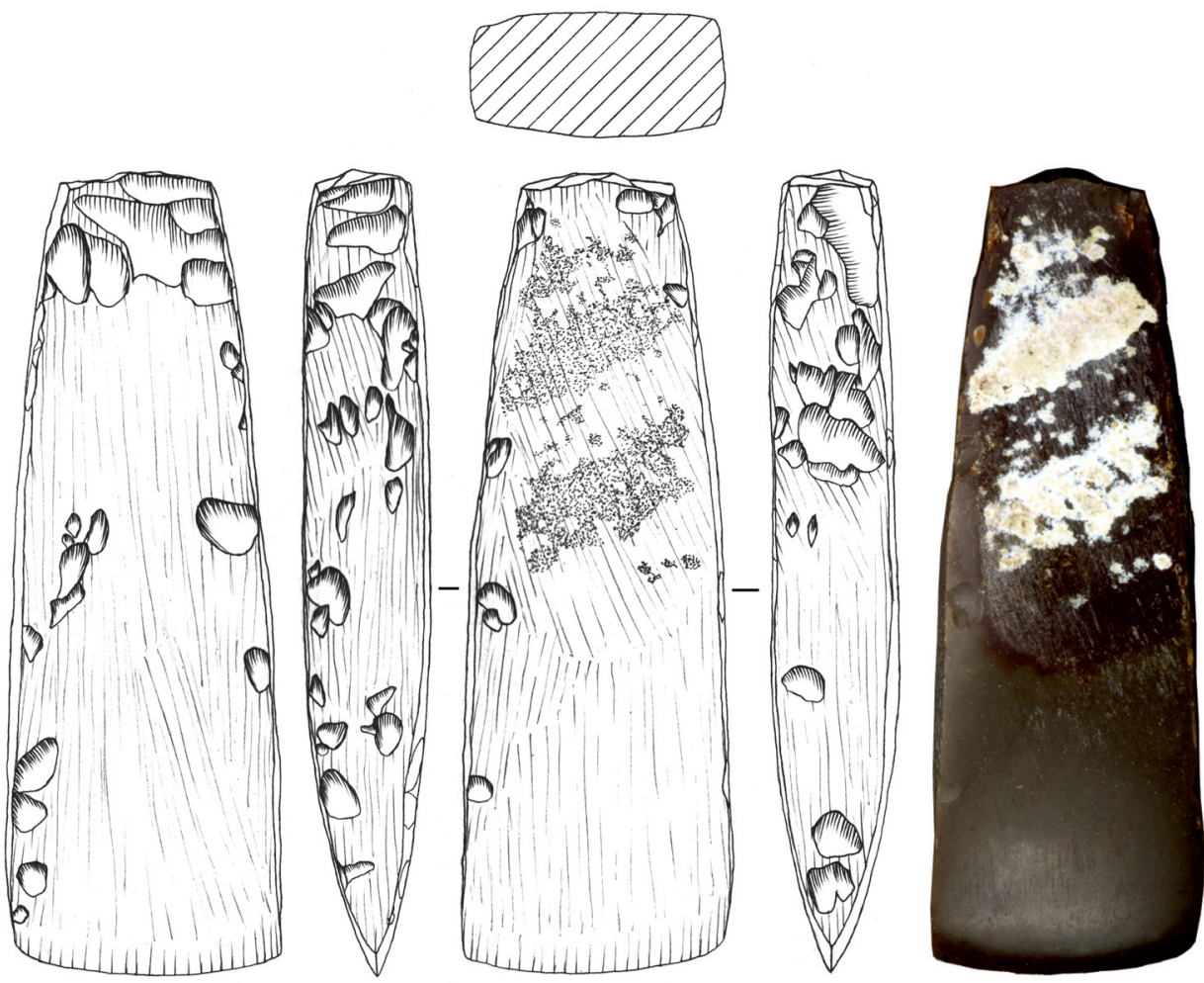

a

0 $5 \mathrm{~cm}$
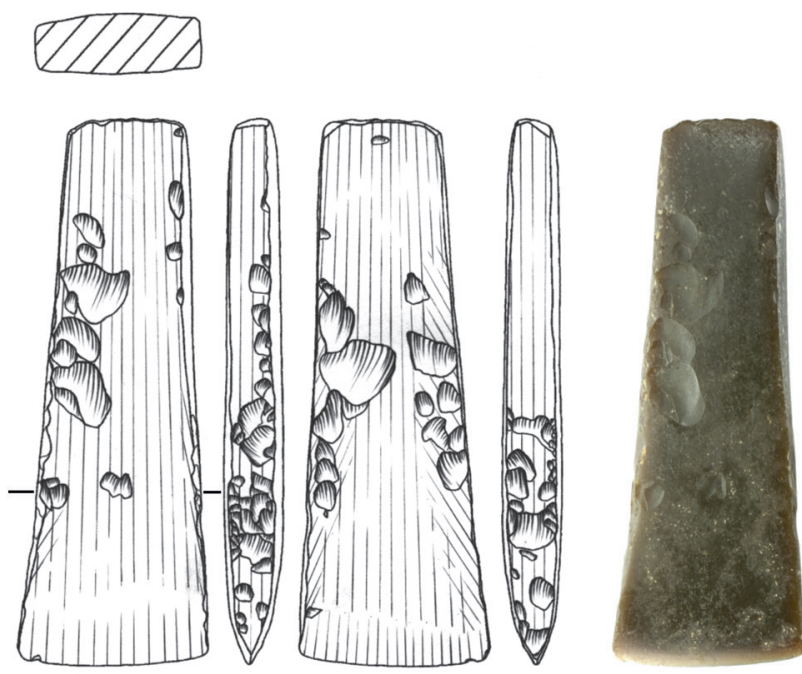
$(68,2 \%)$ daje przedział czasowy 2619-2490 BC. Pozwala to umieścić ten grób w grupie najmłodszych pochówków kultury amfor kulistych z terenu Lubelszczyzny (Bronicki 2016, s. 221; Włodarczak 2016a, s. 541, 545, tabela 2: 8, ryc. 1). Niestety, ze względu na brak zachowanego materiału organicznego datowanie radiowęglowe grobu z Końskowoli nie było możliwe. Późną metrykę obu grobów wydaje się natomiast potwierdzać obecność dużych naczyń z ornamentem sznura (por. Włodarczak 2016a, s. 541). Być może więc mamy tutaj do czynienia z grobami z najmłodszego horyzontu podgrupy nałęczowskiej, który można zsynchronizować z okresem występowania grobów skrzyniowych typu wschodniolubelskiego, pojawiających się zdecydowanie później od grobów typu nałęczowskiego i w większości występujących w drugiej ćwierci III tysiąclecia BC (Włodarczak 2016a, s. 541, 545).

\section{PODSUMOWANIE I WNIOSKI}

Groby z Puław-Włostowic i Końskowoli bez wątpienia zaliczyć można do podgrupy nałęczowskiej kultury amfor kulistych, choć w wielu aspektach odbiegają nieco od „klasycznych” obiektów typu nałęczowskiego. Są też najprawdopodobniej świadectwem zróżnicowania wewnętrznego w tej podgrupie, wynikającego zapewne z konieczności dostosowania się do lokalnych warunków środowiskowych oraz $\mathrm{z}$ różnic chronologicznych $\mathrm{w}$ funkcjonowaniu poszczególnych obiektów. Przejawem modyfikacji tradycyjnej konstrukcji grobu typu nałęczowskiego jest przede wszystkim obiekt z Końskowoli, gdzie kamienie wapienne zastąpiono lokalnymi skałami narzutowymi.

Nie bez znaczenia wydaje się również lokalizacja analizowanych grobów i ich datowanie. Oba znajdują się już poza zwartą strefą występowania ulokowanych na wysoczyznach stanowisk podgrupy nałęczowskiej i oba położone są w bezpośrednim sąsiedztwie cieków wodnych, w niedalekiej odległości od krawędzi Płaskowyżu Nałęczowskiego. Łącząc ten fakt z możliwością uznania tych obiektów za reprezentujące najmłodszą fazę osadnictwa podgrupy nałęczowskiej kultury amfor kulistych, bardzo ostrożnie założyć można, że mogą być dowodem na przesunięcie się grup/grupy jej ludności i dokumentowują moment swoistego „zejścia” z obszarów wysoczyznowych ${ }^{12}$. Hipoteza ta nabiera zupełnie nowego znaczenia wobec występowania grobów o podobnej konstrukcji na Mazowszu. Na obecnym etapie badań przyjmuje się, że punktem wyjścia dla ekspansji ludności kultury amfor kulistych była strefa Niżu Polskiego. Na około 3000 BC datowane jest pojawienie się osadnictwa tej kultury na Wyżynie Sandomierskiej i nieco później na Wyżynie Lubelskiej oraz Podlasiu. Ludność kultury amfor kulistych przesunęła się także w

12 Poza strefą wysoczyznową znajduje się również grób odkryty przypadkowo w Opolu Lubelskim, pow. opolski położony w Kotlinie Chodelskiej, na granicy ze Wzniesieniami Urzędowskimi. Szczątkowe informacje na temat jego konstrukcji i wyposażenia, a co za tym idzie datowania, nie pozwalają na włączenie go do analizy (Bronicki 2016, s. 161). Nie można jednak wykluczyć, że jego lokalizacja również ma związek z migracją grup ludności kultury amfor kulistych w schyłkowej fazie funkcjonowania podgrupy nałęczowskiej. 
made of banded flint (Ścibior 1984, p. 103; Bronicki 2016, p. 221; cf.: NiezabitowskaWiśniewska, Wiśniewski 2018, pp. 268-269, Fig. 6:1, Pl. III 5).

According to the latest juxtaposition by A. Bronicki, 35 axes were discovered in 20 graves of Nałęczów type, 30 of them were made of banded flint ${ }^{10}, 3$ from flint in the Volhynian type, raw material of the remaining was not determined. Thereby, this author does not mention any specimen of chocolate flint (Bronicki 2016, pp. 245-248, Table 12). From the Nałęczów subgroup of the Globular Amphora culture known are only blades, bladelets, blade-flakes and a few blade tools (trapezes, endscraper on a sickle blade and a truncated blade) made from this raw material ${ }^{11}$ as well as single flakes (Bronicki 2016, pp. 246-249, Table 12). The axes from chocolate flint have not yet been discovered also among the inventories coming from other types of graves of Globular Amphorae culture known from the Lublin region (cf. Nosek 1967, pp. 323-324, 364; Bronicki 2016, pp. 239-241).

Dating the grave in Puławy-Włostowice can be based on the ${ }^{14} \mathrm{C}(4040 \pm 35 \mathrm{BP})$ determination from a human bone, which after conversion to calendar age (68.2\%) gives the time interval 2619-2490 BC. This allows to place this grave in the group of the youngest burials of the Globular Amphora culture from the area of the Lublin region (Bronicki 2016, p. 221; Włodarczak 2016a, pp. 541, 545, Table 2:8, Fig. 1). Unfortunately, due to the lack of preserved organic material, radiocarbon dating of the grave from Końskowola was not possible. The late metrics of both graves seem to be confirmed by the presence of large vessels with a cord ornament (cf. Włodarczak 2016a, p. 541). So perhaps we are dealing here with the graves from the youngest horizon of the Nałęczów subgroup, which can be synchronized with the period of the occurrence of box graves of Eastern-Lublin type, appearing much later than the graves of the Nałęczów type and mostly in the second quarter of the third millennium BC (Włodarczak 2016a, pp. 541, 545).

\section{SUMMARY AND CONCLUSIONS}

The graves from Puławy-Włostowice and Końskowola undoubtedly belong to the Nałęczów subgroup of the Globular Amphora culture, although in many aspects they diverge slightly from the "classic" features of the Nałęczów type. They are also most likely an evidence of internal diversity in this subgroup, probably due to the need to adapt to local environmental conditions as well as resulting of chronological differences in the functioning of individual features. A manifestation of the modification of the traditional structure of the grave of the Nałęczów type is primarily the feature from Końskowola, where limestone stones were replaced by local erratic rocks.

${ }^{10}$ A. Bronicki also included to this collection two specimens from Puławy-Włostowice, both considered to be made of banded flint. In fact, only one of the axes is made of this raw material.

${ }_{11}$ According to A. Bronicki, a total of 22 blade products were discovered in the twelve graves of this subgroup, 13 of which were made of chocolate flint (Bronicki 2016, p. 248). 
kierunku Wołynia i Podola, przy czym powstanie jej zespołów w Europie wschodniej, określanych mianem wschodniej grupy kultury amfor kulistych, zsynchronizować można z klasyczną fazą rozwoju tej jednostki kulturowej na ziemiach polskich. Prawdopodobnie pierwsi osadnicy kultury amfor kulistych pojawili się na Wołyniu u schyłku IV tysiąclecia BC (około 3000-2950 BC), docierając tam z Wyżyny Lubelskiej (np. Kadrow, Szmyt 1996, s. 110; Szmyt 1996, s. 9-12; taż 2010, s. 81, 195, $203-$ 204; Kośko, Szmyt 2011, s. 213; Włodarczak 2016b, s. 553-554). Efektem procesu zasiedlenia obszarów Europy wschodniej była „Zwrotna transmisja”, przejawiająca się pojawieniem elementów wschodnich na terenie ziem polskich, niekiedy łączonych z powrotną migracją ludności grupy wschodniej kultury amfor kulistych $\mathrm{w}$ rejon Wisły. Cechy „wschodnie” widoczne są zwłaszcza na obszarach między Wisłą a Bugiem, na północnym Mazowszu i na Wyżynie Sandomierskiej, gdzie intensywność ich występowania wzrasta po około 2700 BC. Tym samym znacząca rola Lubelszczyzny w utrzymywaniu stabilnych kontaktów z grupą wschodnią kultury amfor kulistych wydaje się nie budzić wątpliwości (Szmyt 2010, s. 44-51, 204-205; Kośko, Szmyt 2011, s. 214 ryc. 8, s. 216). Wracając do grobów z Puław-Włostowic i Końskowoli, to datowanie pierwszego $\mathrm{z}$ nich, oparte na oznaczeniu ${ }^{14} \mathrm{C}$, przypada właśnie na okres po 2700 BC. Jak już pisano, grób z Końskowoli najprawdopodobniej datować należy na zbliżony przedział czasowy. W obu wymienionych obiektach nie ma elementów uznawanych za typowe dla wschodnich oddziaływań kultury amfor kulistych, takich jak np. klamry kościane, ornament tzw. rybiej łuski na ceramice, obecność naczyń-pokrywek czy wyrobów z krzemienia wołyńskiego, odnotowywanych także w zespołach grobowych z Płaskowyżu Nałęczowskiego (Szmyt 2010, s. 44-51; Kośko, Szmyt 2011, s. 216). Konstrukcja grobów z Puław-Włostowic i Końskowoli, ich datowanie i niektóre elementy wyposażenia oraz obecność zbliżonych pod względem konstrukcji grobów z obszaru Mazowsza, bardzo ostrożnie pozwalają założyć, że być może są one odzwierciedleniem przemian zachodzących w obrębie społeczności kultury amfor kulistych, w tym przesunięć grup jej ludności. Nie można również wykluczyć, że związane były one z pojawieniem się nowych „impulsów” ze strefy wschodniej kultury amfor kulistych. Określenie dokładnych kierunków ${ }^{13}$ i charakteru domniemanych przesunięć ludnościowych, w tym głównie w skali mikroregionalnej, których manifestacją może być powstanie obiektów w Puławach-Włostowicach i Końskowoli, utrudnia jednak w dalszym ciągu niewystarczająca liczba datowań radiowęglowych dla grobów z niżowego obszaru Lubelszczyzny i Mazowsza.

${ }^{13}$ Według dawnej koncepcji S. Noska, idea grobów obecnie określanych jako typ nałęczowski przejęta została od ludności kultury pucharów lejkowatych i musiało do tego dojść na terenie powiatu puławskiego. Stamtąd, w nieco zmodyfikowanej formie, manifestującej się obecnością podobnych konstrukcji kamiennych, ale wykonanych z kamieni polnych, idea ta wraz z ludnością kultury amfor kulistych przedostała się wzdłuż Wisły na północ, aby ostatecznie dotrzeć na Kujawy (Nosek 1967, s. 345; por. Wiślański 1966, s. 88-89; Kempisty 1971, s. 32). Choć koncepcja ta, głównie odnośnie do genezy grobów typu nałęczowskiego, obecnie nie znajduje uzasadnienia (por. Włodarczak 2016b, s. 553), wskazuje jednak na możliwy kierunek przesunięć ludnościowych w obrębie kultury amfor kulistych. 
The location of the analyzed graves and their dating are significant. Both of them are already situated outside the compact zone of occurrence, located on the plateaus of the Nałęczów subgroup sites. They are also both located in the immediate vicinity of watercourses, not far from the edge of the Nałęczów Plateau. Combining this fact with the possibility of recognizing these objects as the youngest settlement stage of the Nałęczów subgroup, it can carefully be assumed that they may be proof of a shift in the group/groups of population. Not only that, they can document the moment of a sui generis "descent" from the plateau areas ${ }^{12}$. This hypothesis takes on a completely new meaning in the presence of graves with a similar structure in Mazovia. At the current stage of research it is assumed that the starting point for the expansion of the Globular Amphora culture population was the zone of the Polish Lowland. The emergence of the settlement of this culture on the Sandomierz Upland is dated at around $3000 \mathrm{BC}$ and a bit later on the Lublin Upland and in Podlasie. The population of Globular Amphora culture also shifted towards Wolhynia and Podolia, and the creation of its complexes in Eastern Europe, referred to as the Eastern Group of the Globular Amphora culture, can be synchronized with the classical phase of development of this cultural unit on the Polish territories. Probably, the first settlers of Globular Amphora culture appeared in Volhynia at the end of the fourth millennium BC (around 3000-2950 BC), arriving there from the Lublin Upland (e.g. Kadrow, Szmyt 1996, p. 110; Szmyt 1996, pp. 9-12; eadem 2010, pp. 81, 195, 203-204; Kośko, Szmyt 2011, p. 213; Włodarczak 2016b, pp. 553-554). The effect of the process of settling in Eastern Europe was the "reverse transmission", manifested by the appearance of eastern elements in Polish territories, sometimes combined with the return migration of the population of the Eastern Group of the Globular Amphora culture to the Vistula region. The "eastern" features are particularly visible in the areas between the Vistula and the Bug, in northern Mazovia and on the Sandomierz Upland, where the intensity of their occurrence increases after about $2700 \mathrm{BC}$. Thus, the significant role of the Lublin region in maintaining stable contacts with the Eastern Group of Globular Amphora culture does not seem to raise any doubt (Szmyt 2010, pp.44-51, 204-205; Kośko, Szmyt 2011, p. 214, Fig. 8, p. 216). Returning to the graves from Puławy-Włostowice and Końskowola, the dating of the first of them, based on the ${ }^{14} \mathrm{C}$ determination, falls on the period after $2700 \mathrm{BC}$. As has been already written, the grave from Końskowola is most likely to be dated to a similar time interval. In both features there are no elements considered typical for the eastern influences of the Globular Amphora culture, such as, for example, bone buckles, the so-called fish-scale ornamentation on pottery, the presence of pot-lids or products from the Volhynian flint, which are also recorded in burial complexes from the Nałęczów Plateau (Szmyt 2010, pp. 44-51; Kośko, Szmyt 2011, p. 216). The structure of graves from Puławy-Włostowice and Końskowola,

${ }^{12}$ Outside the upland zone, there is also a grave discovered accidentally in Opole Lubelskie, Opole district located in the Chodelka Basin, on the border with Urzędów Heights. Residual information about its construction and equipment, and thus dating, do not allow its inclusion in the analysis (Bronicki 2016, p. 161). It cannot be ruled out, however, that its location is also related to the migration of population groups of the Globular Amphora culture in the end of functioning of the Nałęczów subgroup. 
Znacznie trudniej ustosunkować się do obecności w grobach z Puław-Włostowic i Końskowoli siekier wykonanych z krzemienia czekoladowego. Być może jest to przejaw lokalnej tradycji, świadczący pośrednio o możliwości łączenia obu tych grobów z jedną grupą ludności kultury amfor kulistych, która opuściła obszar Płaskowyżu Nałęczowskiego. Nie można również wykluczyć, że krzemień czekoladowy wykorzystano do produkcji siekier w związku z brakiem (chwilowym?) dostępu do innego surowca.

Nadmienić należy również, że nie są to jedyne stanowiska podgrupy nałęczowskiej kultury amfor kulistych położone poza wysoczyznowym obszarem Płaskowyżu Nałęczowskiego. Duże skupisko fragmentów ceramiki tej kultury odkryto między innymi w trakcie badań powierzchniowych na wydmie znajdującej się na północ od stanowiska w Puławach-Włostowicach (Niezabitowska-Wiśniewska, Wiśniewski 2018, s. 263-264, 271, tabl. IV; V) ${ }^{14}$ oraz na obszarze Kotliny Chodelskiej (por. Zawiślak 2016, s. 63 ryc. 4). Być może, część z tych śladów osadniczych również jest pozostałością zniszczonych grobów, czego jednak nie da się stwierdzić bez badań wykopaliskowych.

Omówione groby z Puław-Włostowic i Końskowoli stanowią doskonały przyczynek do dalszych studiów nad podgrupą nałęczowską kultury amfor kulistych, w tym przede wszystkim nad jej schyłkiem. Bezsprzecznie też wskazują na konieczność kontynuowania badań w strefie krawędziowej Płaskowyżu Nałęczowskiego.

${ }^{14}$ Badania powierzchniowe na tych wydmach przeprowadził w 1949 r. Leszek Gajewski. Niestety nie znamy ich dokładnej lokalizacji. Materiały znajdują się w zbiorach Instytutu Archeologii Uniwersytetu Marii Curie-Skłodowskiej w Lublinie. 
their dating and some elements of burial goods as well as the presence of graves of similar structure from the area of Mazovia, very cautiously allow to assume that they may be a reflection of changes occurring within the community of the Globular Amphora culture, including shifts of its population groups. It cannot be ruled out that they were associated with the appearance of new "impulses" from the eastern zone of the Globular Amphorae culture. Defining the exact directions ${ }^{13}$ and nature of alleged population transfers, mainly on the micro-regional scale, which may be manifested by emerging of the features in Puławy-Włostowice and Końskowola, is still hampered by the insufficient number of radiocarbon dating for graves coming from low-laying areas of the Lublin region and from Mazovia.

It is much harder to interpret the presence of axes made of chocolate flint in the graves from Puławy-Włostowice and Końskowola. Perhaps both of these graves belonged to a subgroup of the Globular Amphora culture that left the Nałęczów Plateau area. It is also possible that the chocolate flint was used to produce axes due to the (temporary?) lack of access to another raw material.

It should also be mentioned that these are not the only sites of the Nałęczów subgroup of the Globular Amphora culture located outside the upland area of the Nałęczów Plateau. A large concentration of pottery fragments of this culture was discovered, inter alia, during a surface research on a dune located north of the site in Puławy-Włostowice (Niezabitowska-Wiśniewska, Wiśniewski 2018, pp. 263-264, 271, Pls IV; V) ${ }^{14}$ or in the area of Chodelka River Valley (cf. Zawiślak 2016, p. 63, Fig. 4). Perhaps, some of these settlement traces are also a remnant of destroyed graves, what, however, cannot be proved without archaeological excavations.

The graves from Puławy-Włostowice and Końskowola as discussed here are an excellent contribution to further studies on the Nałęczów subgroup of the Globular Amphora culture most importantly including its decline. Undoubtedly, they also indicate the necessity of continued research in the edge zone of the Nałęczów Plateau.

Translated by Andrzej Leligdowicz

${ }^{13}$ According to the old concept of S. Nosek, the idea of graves, currently referred to as the Nałęczów type, was taken over from the Funnel Beaker culture population and had to be found in the Puławy district. From there, in a slightly modified form, manifested by the presence of similar stone constructions, but made of field stones, this idea along with the population of Globular Amphora culture got along the Vistula to the north, to reach finally Kuyavia (Nosek 1967, p. 345; cf. Wiślański 1966, pp. 88-89; Kempisty 1971, p. 32). Although this concept, mainly regarding the genesis of the type of Nałęczów graves, is currently not justified (cf. Włodarczak 2016b, p. 553), however, it points to the possible direction of population shifts within the Globular Amphora culture.

${ }^{14}$ Surface research on these dunes was carried out in 1949 by Leszek Gajewski. Unfortunately, we do not know their exact location. The materials can be found in the collections of the Institute of Archaeology of the Maria Curie-Skłodowska University in Lublin. 


\section{WYKAZ CYTOWANEJ LITERATURY}

\section{BIBLIOGRAPHY OF WORKS CITED}

A bre u-Głow a cka M., M i chal a k E. 2018, Badania genetyczne szczątków ludzkich $z$ grobu kultury amfor kulistych ze stanowiska 3 w Puławach-Włostowicach, Sum.: Genetic analysis of human remains from a grave of the Globular Amphorae culture at site 3 in Puławy-Włostowice, [in:] B. Niezabitowska-Wiśniewska, Puławy-Włostowice. Wielokulturowe stanowisko z zachodniej Lubelszczyzny, Lublin, pp. 302-309.

B r o n i ck i A. 2016, Obrzadek pogrzebowy społeczności kultury amfor kulistych na Wyżynie Lubelskiej, Sum.: The burial ritual of the Globular Amphora societies on the Lublin Upland, [in:] Schyłek neolitu na Wyżynie Lubelskiej, P. Jarosz, J. Libera, P. Włodarczak eds., Kraków, pp. 45-256.

Hali cki M. 1970, Cmentarzyska kultury amfor kulistych i kultury pucharów lejkowatych w Klementowicach, pow. Puławy na stanowisku IV, Sum.: The cemeteries of the Globular Amphora and Funnel Beaker cultures at Klementowice, Puławy district, site IV, „Wiadomości Archeologiczne", 35/3, pp. 303-326.

Jakubczak M. 2018, Wykorzystanie wysokorozdzielczych numerycznych modeli terenu $w$ badaniach stanowisk płaskich, Sum.: Use of high-resolution digital surface models in the study of site not visible on terrain relief, [in:] B. Niezabitowska-Wiśniewska, Puławy-Włostowice. Wielokulturowe stanowisko z zachodniej Lubelszczyzny, Lublin, pp. 142-153.

K a d r o w S., S z m y t M. 1996, Absolute chronology of the eastern group of Globular Amphora culture, [in:] Eastern exodus of the Globular Amphora people: 2950-2350 BC, A. Kośko ed., „Baltic-Pontic Studies”, 4, pp. 103-111.

Ke m p ist y E. 1971, Kultura amfor kulistych na Mazowszu i Podlasiu, Sum.: The Globular Amphora culture in Masovia and Podlachia, „Materiały Starożytne i Wczesnośredniowieczne", 1, pp. 7-34.

Ko n d r a c k i J. 2009, Geografia regionalna Polski, Warszawa.

Ko śko A., S z m y t M. 2011, Udział społeczności Niżu Środkowoeuropejskiego w poznaniu środowisk biokulturowych Ptyty Nadczarnomorskiej: IV - IV/III tys. BC, Sum.: Central European Lowland societies and the Pontic area in the $4^{\text {th }}$ and $4^{\text {th }}-3^{\text {rd }}$ millennium $B C$ [in:] Między Bałtykiem a Morzem Czarnym. Szlaki międzymorza IV - I tys. przed Chr., M. Ignaczak, A. Kośko, M. Szmyt eds., Poznań, pp. 205-221.

K o w a l c z y k J. 1953, Dwa groby kultury amfor kulistych z Lasu Stockiego i Stoku, Sum.: Two graves of „the globular amphorae culture”, „Sprawozdania P.M.A., 5, pp. 38-47.

Kowalczyk J. 1968, Dwa zespoły neolityczne datowane radioweglem, Sum.: Radiocarbon dating of two neolithic complexes of finds, „Wiadomości Archeologiczne”, 33/3-4, pp. 368-376.

Kozak-Zy chm a n W., S z eli g a M. 2004, Pochówki ludności kultury amfor kulistych na Lubelszczyźnie, [in:] Przez pradzieje i wczesne średniowiecze. Księga jubileuszowa na siedemdziesiąte piate urodziny docenta doktora Jana Gurby, J. Libera, A. Zakościelna eds., Lublin, pp. 127-138.

Libera J., Taras H. 2011, Epoka neolitu i początki epoki brazu na Polesiu Lubelskim, Sum.: The Neolithic period and Early Bronze Age in Lublin Polesie, [in:] Na rubieży kultur. Badania nad okresem neolitu i wczesna epoka brazu, U. Stankiewicz, A. Wawrusiewicz eds., Białystok, pp. 37-54.

L orkiewicz-Muszyńska D., Glapiński M., Ko cie mba W. 2018, Analizaantropologiczna i odontologiczna ludzkich szczątków kostnych z grobu kultury amfor kulistych 
ze stanowiska 3 w Puławach-Włostowicach, Sum.: Anthropological and odontological analysis of human skeletal remains from a grave of the Globular Amphorae culture at site 3 in Puławy-Włostowice, [in:] B. Niezabitowska-Wiśniewska, Puławy-Włostowice. Wielokulturowe stanowisko z zachodniej Lubelszczyzny, Lublin, pp. 284-301.

Matyaszewski M., Miliszkiewicz G. 1978, Puławy-Włostowice woj. lubelskie. Stanowisko 2, „Informator Archeologiczny. Badania rok 1977”, p. 139.

N i e z a b i t o w s k a - W iśn i e w s k a B. 2018, Stanowisko w Puławach-Włostowicach wświetle archiwaliów, Sum.: Puławy-Włostowice site in light of archive records, [in:] B. Niezabitowska-Wiśniewska, Puławy-Włostowice. Wielokulturowe stanowisko z zachodniej Lubelszczyzny, Lublin, pp. 18-125.

Ni e za bitowska-Wiśn iewska B., Wiśn i e wski T. 2018, Osadnictwo ludności kultur amfor kulistych i ceramiki sznurowej, Sum.: Settlement of the populations of the Globular Amphorae culture and Corded Ware culture, [in:] B. Niezabitowska-Wiśniewska, Puławy-Włostowice. Wielokulturowe stanowisko z zachodniej Lubelszczyzny, Lublin, pp. 262-282.

N o s e k S. [1950] 1954/1955, Kultura amfor kulistych na Lubelszczyźnie, Sum.: The Globular Amphorae culture in the Lublin province, „Annales Universitatis Mariae Curie-Skłodowska", Sectio F, 5/3, pp. 55-158.

N o s e k S. 1967, Kultura amfor kulistych $w$ Polsce, Rés.: La civilisation des amphores globulaires en Pologne, Polska Akademia Nauk Oddział w Krakowie. Prace Komisji Archeologicznej, 8, Wrocław-Warszawa-Kraków.

R e d e r J. 2018, Przyrodnicze uwarunkowania wielokulturowego stanowiska pradziejowego w Puławach-Włostowicach, Sum.: Natural determinants of the location of the multicultural prehistoric site in Puławy-Włostowice, [in:] B. Niezabitowska-Wiśniewska, PuławyWłostowice. Wielokulturowe stanowisko z zachodniej Lubelszczyzny, Lublin, pp. 126-141.

Rychlik M., Lorkiewicz-Muszyńska D., Kocie mba W. 2018, Badania tomografii komputerowej i rekonstrukcja 3D czaszki z grobu kultury amfor kulistych odkrytego w trakcie badań archeologicznych stanowiska 3 w Puławach-Włostowicach, Sum.: Computed tomography and 3D reconstruction of a skull from a grave of the Globular Amphorae culture discovered during excavations at site 3 in Puławy-Włostowice, [in:] B. Niezabitowska-Wiśniewska, Puławy-Włostowice. Wielokulturowe stanowisko z zachodniej Lubelszczyzny, Lublin, pp. 310-327.

S a lewicz K. 1937, Bogato wyposażone groby kultury amfor kulistych z Rębkowa-Parcel w pow. garwolińskim, „Z otchłani wieków”, 12/6, pp. 80-81.

S z m y t M. 1996, Globular Amphora culture in Eastern Europe. Present state of research and possibilities for future studies, [in:] Eastern exodus of the Globular Amphora people: 29502350 BC, A. Kośko ed., „Baltic-Pontic Studies”, 4, pp. 3-27.

S z m y t M. 2010, Between west and east. People of the Globular Amphora culture in eastern Europe: 2950-2350 BC, „Baltic-Pontic Studies”, 8, Poznań.

Ścibi or J. 1984, Grupa nałęczowska kultury amfor kulistych. Część 1. Katalog źródeł. Część II. Analiza, manuscript of the Master's Thesis stored in the Archive of the Institute of Archaeology, Maria Curie-Skłodowska University, Lublin.

Ś c i b i or J. 1985a, Grupa nałęczowska kultury amfor kulistych, Archeologiczne Listy, 2, Lublin.

Ś c ib i or J. 1985b, Groby ludności kultury amfor kulistych w Rudnie, woj. bialskopodlaskie, [in:] Lubelskie Materiały Archeologiczne, J. Gurba ed., Lublin, pp. 65-77.

Ś c i b i o r J. 1986, Nowe stanowiska grupy mazowiecko-podlaskiej kultury amfor kulistych, Sum.: New sites of the Masovian-Podlasie group of the Globular Amphora culture, „Sprawozdania Archeologiczne", 38, pp. 109-127. 
Ś c i b i o r J. 1991, Kultura amfor kulistych w środkowowschodniej Polsce. Zarys problematyki, [in:] Schyłek neolitu i wczesna epoka brązu w Polsce środkowowschodniej (materiały z konferencji), J. Gurba ed., Lubelskie Materiały Archeologiczne, VI, Lublin, pp. 47-65.

Uz a r o w i c z o w a A. 1968, Grób kultury amfor kulistych na stanowisku I w Klementowicach, pow. Puławy, Sum.: A grave of the Globular Amphorae culture at site I at Klementowice, Puławy district, „Wiadomości Archeologiczne”, 33/2, pp. 217-223.

W i śl a ń s k i T. 1966, Kultura amfor kulistych w Polsce pótnocno-zachodniej, Sum.: Globular Amphorae culture in North-West Poland, Wrocław.

W ł o d a r c z a k P. 2016a, Chronologia absolutna cmentarzysk późno- $i$ schyłkowoneolitycznych na Wyżynie Lubelskiej, Sum.: Absolute chronology of Late and Final Neolithic cemeteries on the Lublin Upland, [in:] Schytek neolitu na Wyżynie Lubelskiej, P. Jarosz, J. Libera, P. Włodarczak eds., Kraków, pp. 537-548.

W ł o d a r c z a k P. 2016b, Dwa rytuały, dwie społeczności, dwie epoki, dwa światy? Obrządek pogrzebowy w późnym i schyłkowym neolicie na Wyżynie Lubelskiej, Sum.: Two rituals, two communities, two epochs, two worlds? The funerary ritual in the Late and Final Neolithic on the Lublin Upland, [in:] Schyłek neolitu na Wyżynie Lubelskiej, P. Jarosz, J. Libera, P. Włodarczak eds., Kraków, pp. 549-561.

$\mathrm{Z}$ a k oś c i el n a A. 2000, Badania ratownicze cmentarzyska kultury amfor kulistych $w$ Nadrybiu-Dworze, stan. 3, gm. Puchaczów, pow. Łęczna, Sum.: Rescue excavations at a cemetery of the Globular Amphora culture in Nadrybie-Dwór, site 3, Łęczna District, „Archeologia Polski Środkowowschodniej", 5, pp. 51-57.

Z a w i śl a k P. 2016, Kultura amfor kulistych $w$ świetle odkryć towarzyszacych inwestycjom drogowym w województwie lubelskim, [in:] Drogi Lubelszczyzny. Odkrycia i badania archeologiczne, E. Banasiewicz-Szykuła ed., Skarby z Przeszłości, 17, Lublin, pp. 59-77. 